\title{
Volatility drivers on the metal market and exposure of producing countries
}

\author{
Sven Renner ${ }^{1,2}$ (D) Friedrich W. Wellmer ${ }^{3}$
}

Received: 10 April 2019 / Accepted: 18 June 2019 / Published online: 19 August 2019

(C) The Author(s) 2019

\begin{abstract}
The paper focuses on minor metals and coupled elements and aspires to understand individual incidents of imbalance on the mineral markets during the last 100 years and gain insight into the acting dynamics - those dynamics are commodity-specific but remain largely unchanged in their nature to date - and to identify the factors in play. The conclusions allow for a critical analysis of the widespread security-of-supply narrative of industrialized countries. They point at a market that is mostly a buyers' market, in which prices and their volatility are largely dictated by shifting demand patterns and much less by supply constraints. Neither high country concentration nor poor governance seem to have a substantial or lasting impact on market balance. Short-term market imbalances are generally neutralized by a dynamic reaction on the demand side via substitution, efficiency gains or technological change. The paper also assesses the impact of those quickly shifting demand patterns and the related price volatilities on producing countries. It shows how mineral price volatilities can expose developing countries' economies to significant economic risk, if their economy is heavily dependent on mineral production. Two cases that illustrate country exposure are explored in detail - the saltpeter crisis in Chile and the tin crisis in Bolivia. Both led to state bankruptcy. The paper concludes with an attempt to quantify economic exposure of producing countries to price volatilities of specific metals and suggests policies that adapt to the characteristic challenges of highly volatile demand.
\end{abstract}

Keywords Minerals $\cdot$ Metals $\cdot$ Volatility $\cdot$ Raw materials $\cdot$ Substitution $\cdot$ Low-income countries

JEL classification $\mathrm{O} 11 \cdot \mathrm{O} 13 \cdot \mathrm{O} 14 \cdot \mathrm{O} 23 \cdot \mathrm{O} 25 \cdot \mathrm{O} 33 \cdot \mathrm{O} 38 \cdot \mathrm{Q} 31 \cdot \mathrm{Q} 32 \cdot \mathrm{Q} 33 \cdot \mathrm{Q} 34 \cdot \mathrm{Q} 38$

\section{Introduction}

In contrast to manufactured products, mineral raw materials do not have unique selling points. They are traded globally, be it via bilateral agreements or in commodities future exchanges

Friedrich W. Wellmer is the former president of the German Federal Institute for Geosciences and Natural Resources.

Electronic supplementary material The online version of this article (https://doi.org/10.1007/s13563-019-00200-8) contains supplementary material, which is available to authorized users.

Sven Renner

srenner1@worldbank.org

1 The World Bank, 1818 H St NW, Washington, DC 20433, USA

2 University of Dundee, Nethergate, Dundee DD1 4HN, UK

3 Hannover, Germany as is the case for base metals on the London Metal Exchange (LME) or crude oil on the International Petroleum Exchange, against one or several standards based on their physical and chemical specifications.

The significant decline of transportation costs and increased vessel capacity since the industrial revolution has led to a truly globalized market for mineral commodities, in which industrialized countries depend on mineral imports (those not produced domestically) and many producing countries depend on the export of their mineral products.

In this global marketplace, small shortfalls or surpluses can lead to significant price variations, creating volatility (Wellmer et al. 2018) — with local markets, the fluctuations probably would be even higher, but only locally. Due to their nature as commodities, price volatility of minerals has always been higher than for manufactured products (Jacks et al. 2011).

For a closer analysis, in this work, we will distinguish three groups of commodities: major metals, minor metals, and 
coupled elements. Major metals are, for example, aluminum, copper, lead, zinc, or tin which occur in own deposits; minor metals may occur in own deposits like tantalum but are often by-product metals which do not have own deposits but occur with the major metals in their deposits. Examples are germanium or gallium. Coupled elements are groups of elements like the rare earth or the platinum group elements that due to chemical similarities always occur together in deposits.

Price volatilities and the underlying market imbalances have brought about supply security concerns in industrialized countries. Lists of critical minerals, especially of minor metals, are compiled and are continuously reviewed based on criteria such as country concentration of production and governance indicators in these countries, a narrative that this paper puts to scrutiny.

On the part of producing countries, the impact of market imbalances is different. Especially if their economy is heavily depending on mineral production, price volatility can put a heavy burden on economic development and growth. Earlier work has shown that price volatilities of different mineral commodities are driven by different factors (Wellmer et al. 2018). Yet largely unclear is the impact these different volatility patterns have on development and growth in producing countries. This paper provides analysis of historic cases and approach to quantify economic exposure of producing countries.

A principal remark at the beginning: Price volatility is a basic element of a functioning commodity market. It provides the market with information necessary for securing supply. While excess supply and following price collapses can be disastrous for a supply country, the opposite is true for a consuming country (as long as trade flow is not discontinued). Price peaks due to shortages prompt reactions on both sides - demand and supply. On the demand side, consumers will reduce material intensity or develop and use alternative materials by substitution. On the supply side, higher prices encourage the expansion of existing sources of primary supply, the finding and developing of new primary resources, as well as increasing recycling and secondary production (Tilton et al. 2018). The combination of these dynamics keeps the so-called feedback control cycle of mineral supply in motion and brings back to balance demand and supply (Wellmer and Dalheimer 2012; Wellmer and Hagelüken 2015). Shortages and price peaks therefore generally disappear in a relatively short period of time.

\section{Supply-side-driven volatility}

Supply-side-driven market imbalances that entail price volatilities would be expected when the global production runs counter to demand or changes abruptly. Sudden changes of global production may be caused by the opening or closure of an individual operation, if the operation has a significant share in global production. Other supply-side-driven imbalances may relate to stalled production in a specific country due to fragility and conflict, if that country provides a significant share to global production.

\section{Market share of individual mining/refining operations}

Mine operators are reluctant to closing a mine permanently or for care and maintenance. Especially closing and restarting a large-scale production unit is a complex, costly, and timeconsuming undertaking. Especially in developing nations, contractual obligations put additional obstacles to closure of a mine. As opposed to this, small operations especially those of by-product metals, which often are auxiliary facilities in larger smelters, can be closed and restarted quickly.

Due to the globally smaller production volume combined with scale economics, producers of by-products generally have a larger market share than those of main metals. A parameter frequently used to capture the market share of production units is the share of the five largest production companies in relation to world production. Figure 1 displays the market share of the five largest producers vs. global production in tons. There is a clear correlation that indicates that individual market shares of minor metal producers are generally larger than for major metals (with the five largest producers of germanium accounting for almost $80 \%$ of global production). Major metals generally have a much larger number of producers and smaller individual market shares (the five largest copper producers accounting for less than $20 \%$ of the production). Closing or opening a minor metal production facility therefore should have a higher impact on total production and be more likely to disbalance the markets.

Figure 2 displays average price volatilities for selected metals against global production. The graph shows no clear increase of

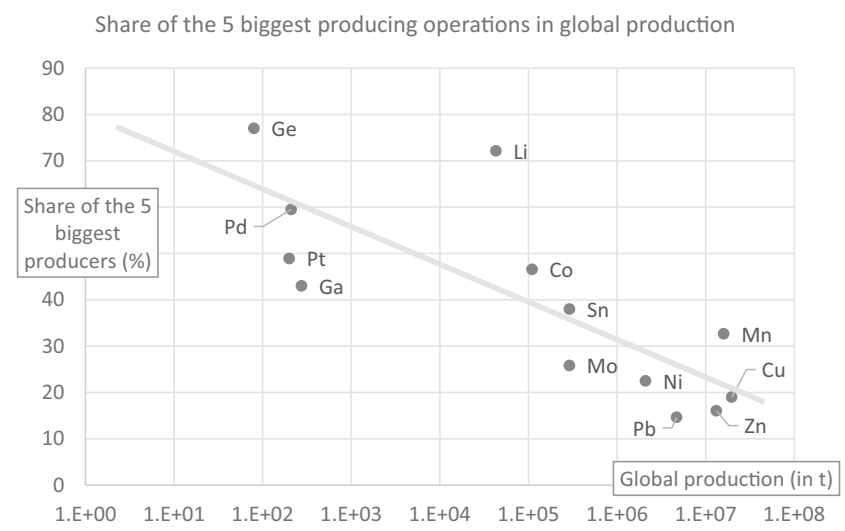

Fig. 1 Trend: total world production (in t) plotted against the share of the five largest producers globally. Linear interpolation $(y=-1.585+$ $\left.15.7599, r^{2}=0.615\right)$. Sources ICSG 2007 and $2018(\mathrm{Cu})$, Liedtke and Huy 2018 (Ga), Melcher and Buchholz 2014 (Ge), BGR data base 2018 (Sn), other commodities S\&P-Standard and Poor's market intelligence (2019) 
Fig. 2 Price volatility plotted against global production. There is no clear correlation between smaller production and volatility. However, smaller production does translate in a higher range of volatility. Volatility ( $y$-axis) is calculated by the authors as the average of a moving standard deviation (1975-2012) with a 7year window, based on USGS price data. (USGS Historical Statistics 2019)

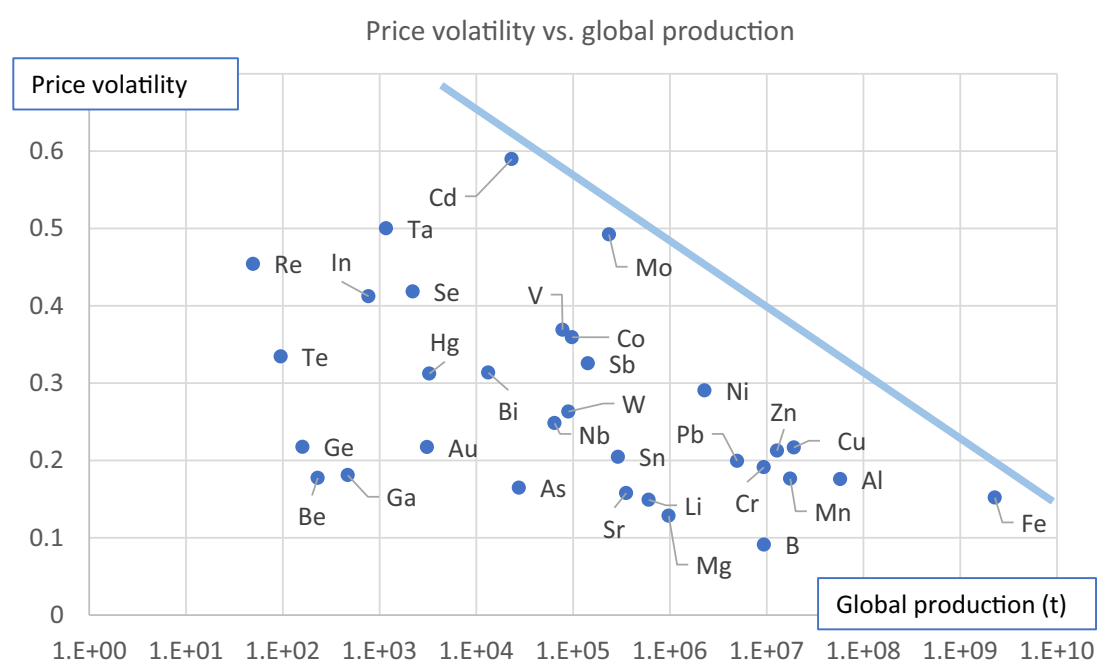

volatility for minerals with a smaller production, but there seems to be a volatility ceiling that is higher for minor metals and lower for major metals. This may reflect the fact that volatilities are not constant over time and are likely to be triggered by specific events. Hence, the volatility of a specific metal will depend on the selected window of time. While Fig. 2 suggests that minor metals are more prone to volatility than major metals, the causality for this is not entirely clear. The impact of closing or opening a single mine may explain part of Fig. 2. But there may be other factors in play, especially on the demand side, that drive the higher volatility of minor metals, as discussed in "Demandside-driven volatility" section.

\section{Country risk}

Industrialized countries have been adopting "mineral strategies" or "raw material strategies" based on supply risk assessments. The rationale of mineral strategies is driven by the concern of securing mineral supply for their national industry demand and of suffering supply bottlenecks. Special regard is given to "critical" minerals needed to supply strategic industries such as high-tech or military. Criticality is rated higher if the mineral production is concentrated in few countries. This country concentration is mostly expressed using the Herfindahl-Hirschmann index (HHI, on a scale between 0 and $10.000^{1}$ ). If production is concentrated in countries of poor governance, this adds to the criticality.

Concentration of production in a small number of countries can reach high levels. For instance, $80 \%$ of the rare earth

\footnotetext{
1 To calculate the HHI, the market share of each producer is squared, and then, all these values are summed. In the economic sciences, it is usual to present the results not as percent, but in values between 0 and 10,000 whereby 10,000 denotes a monopoly and values greater than 2500 are considered critical highly concentrated, and values between 1500 and 2500 are considered moderately concentrated (US Department of Justice and Federal Trade Commission 2010).
}

elements (REEs) originate from China, $55 \%$ of cobalt is produced in the DRC, nearly $90 \%$ of niobium in Brazil, and $72 \%$ of platinum in South Africa. Besides REE, China is the principal source of other raw materials such as indium (44\%), germanium $(63 \%)$, gallium $(>80 \%)$, antimony $(68 \%)$, and vanadium $(53 \%){ }^{2}$

Numerous supply risk assessments were triggered by the commodity supercycle after the turn of the millennium, followed by other studies and publications. Three recent meta-studies compared these evaluations: the studies by Erdmann and Graedel (2011), a report by the UK Energy Research Centre in 2013 (UKERC 2013), and the KRESSE study by the Wuppertal Institute in Germany in 2014 (WI 2014; Viebahn et al. 2015). The German Mineral Resources Agency at the Federal Institute for Geosciences and Natural Resources regularly since 2014 publishes risk assessments for a wide range of commodities (e.g., DERA 2017).

Against this background, it would seem intuitive that price volatility increases with the concentration of supplier countries. This however is not the case (Fig. 3). There is no clear correlation of country concentration and volatility (on the contrary, the figure suggests a tendency of diminishing volatility with increasing country concentration). Surprisingly, adding country risk to the equation does not produce significant correlation with volatility either. Evaluating volatility data from DERA (2019) and weighted country risk data from DERA (2017) reveals no significant correlation. ${ }^{3}$ In other words, in the mineral market, country concentration and country risk are not reflected in a systematic tendency to market imbalance due to shortages.

\footnotetext{
$\overline{2}$ These figures show mere production. They do not consider the share that remains within the producing country and is not made available for importing countries. From an importing country's perspective, concentration of exports would be the more telling parameter.

${ }^{3}$ This is a parameter that is based on the World Governance Index of the World Bank, weighted in accordance with the proportion each country contributes to global production.
} 
There are however examples of shortages produced by conflict in producing countries ("War and civil crises as volatility driver - cobalt" section). But their impact on the markets is limited. In many cases, the reactions to the shortage via substitution are much more lasting than the price peaks caused by the shortage itself. This also applies to market imbalances and artificial shortages produced in an international price agreement or a monopoly setup as shown in "War and civil crises as volatility driver - cobalt" and "The tin crisesmarket interference and volatility" sections.

\section{Demand-side-driven volatility}

\section{Introduction}

Economic cycles are accompanied by raw material demand fluctuations. Production capacity is far less flexible and cannot easily adjust to a changing demand. Markets therefore rarely are in equilibrium; they fluctuate between buyer's and seller's markets (Wellmer et al. 2018). A buyer's market is a market where the buyer determines the price because there is an oversupply and the buyer can put pressure to decrease the prices, and a seller's market is just the opposite. Figure 4 shows the price curves for several mineral commodities and the fundamental difference between major and minor metals. Price peaks for major industrial and steel alloy metals generally follow global economic cycles. As opposed to this, price curves of minor metals are evidently controlled by different drivers.

The main reason for this is that major metals such as copper, steel or aluminum, zinc, lead, or even tin, (the latter with a much smaller annual consumption) have a wide range of applications, which changes only slowly over time. Figure 5 displays the little changes of copper use in a decade. Even smaller changes within a decade occurred for zinc with a usage that remained largely constant (Jorge 2019): galvanizing $50 \%$, zinc alloying $17 \%$, brass and bronze $17 \%$, zinc semimanufactures $6 \%$, chemicals $6 \%$, and others $6 \%$.

For tin, with a much smaller production (in the order of $100,000 \mathrm{t}$ vs. 10 million $\mathrm{t}$ ), the picture seems to be more complex (Fig. 6). However, taking into account a major change which happened in 2006 with the increase in the solder sector, the usage distribution is rather constant and significant changes are happening only in the "Others" sector (Carlin 1985; ITRI 2007, 2017). The change taking place in 2006 was the replacement of lead in solders required by the EU in 2006, which put strict limits on the amount of lead permitted in electronic devices sold in the EU (Ames Laboratory 2008). Because the electronic industry is a global industry, this EU ban practically meant a global ban.

Minor metals, in contrast, are used predominantly in special high-tech applications, where technology changes rapidly. As indicated in "Introduction" section, they frequently are byproducts that do not have deposits of their own but are associated with another primary commodity. The ore processing of the primary commodity and the by-product can be closely interrelated, with the by-product even occurring in the lattice of the minerals of the primary commodity. The recovery of the by-product is unavoidably coupled with the recovery of the main commodity. Normally, the unit price of the main commodities is much lower than the one for minor metals; the total value of the produced main metal, because of its high volume, however, generally is much higher.

Therefore, the impact of volatility on the economies of producing nations is generally far less for by-product metals than for the main metal. An example, germanium is a by-product of zinc mining. In 2016, world mine production of zinc was $12,600,000 \mathrm{t}$. The average price on the London Metal Exchange was US cts126.1/lb zinc, i.e., the total value of zinc
Fig. 3 Contrary to intuition, there is no apparent correlation between country concentration of production and price volatility for individual minerals. Country concentration is expressed using the Herfindahl-Hirschman index, displayed on the $x$-axis. Volatility ( $y$-axis) is calculated by the authors as the average of a moving standard deviation (1975-2012) with a 7-year window, based on USGS price data. (USGS Historical Statistics 2019)
Price volatility vs. $\mathrm{HHI}$

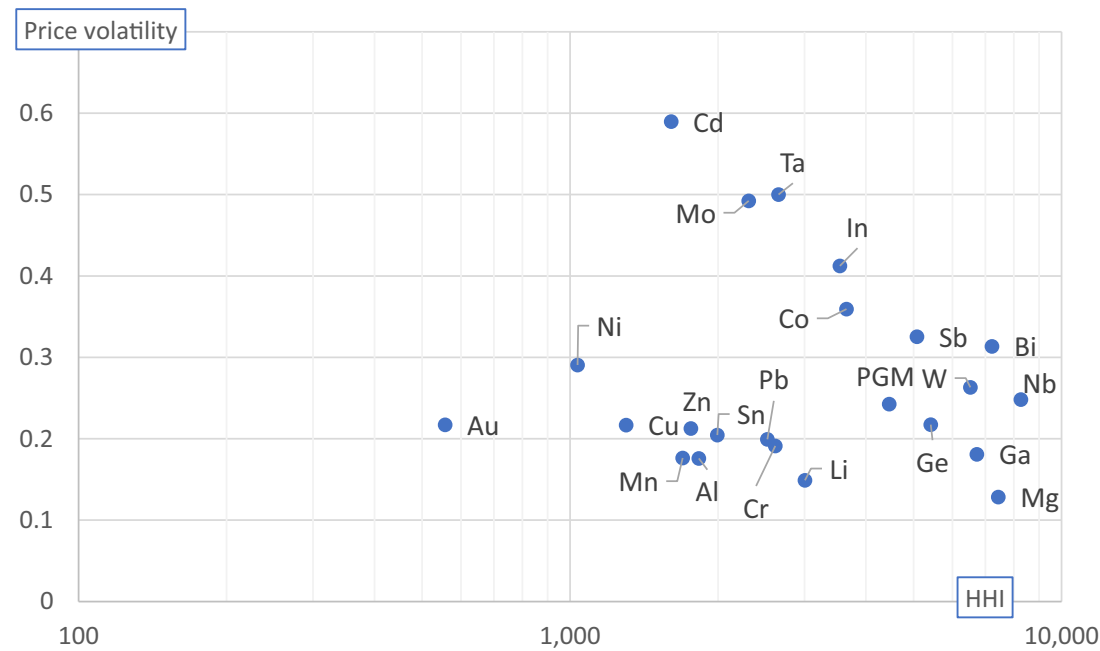


Fig. 4 Relative volatility of "normal" industrial and steel alloy metals (left) and minor metals (right). The prices are shown as real prices (inflation-corrected). (Wellmer et al. 2018 based on Buchholz 2013 and Bräuninger et al. 2013)

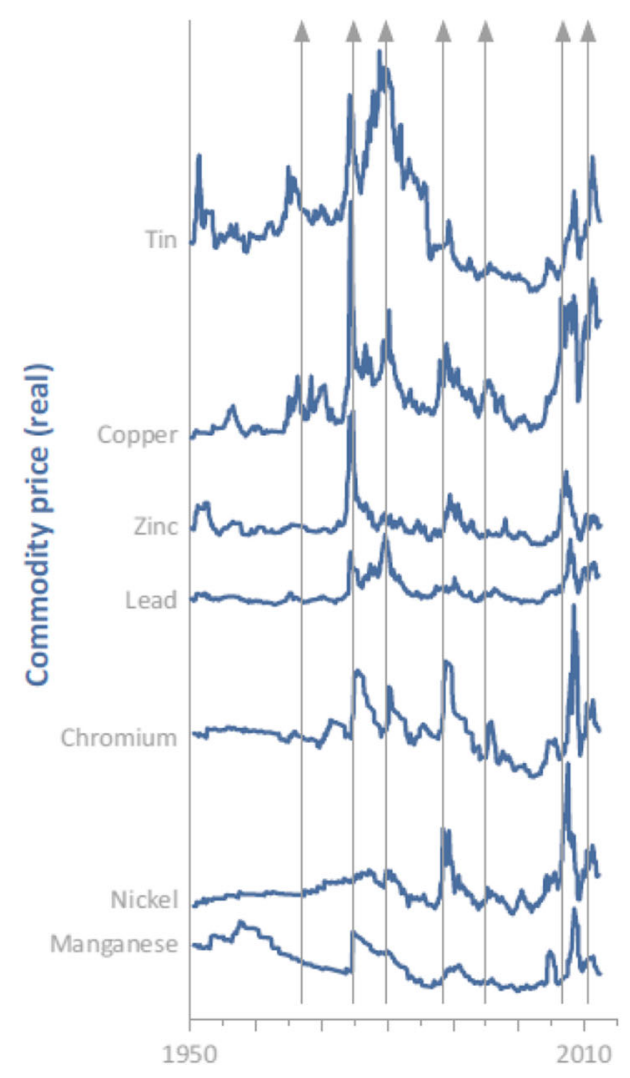

was about US\$35 billion. The production of germanium in 2016 was estimated to be $126 \mathrm{t}$, the price US\$787/kg, i.e., the total value of germanium was approximately US\$100 million (Thomas 2018). There is a factor of several hundred between the total production value of the main commodity and the byproduct. ${ }^{4}$ Exceptions to this rule will be discussed in "Implications for producing countries - the road ahead" section.

It is in the by-product's nature that the feedback control is partially disabled for this group. Nassar et al. (2015) hint at the technological importance of by-products and their problematic supply. As an example, an increase in the price of germanium is unlikely to prompt an increase in zinc mine production. This economic relationship in mining is known as a "price inelasticity of by-product metals." At best, the producer may react quickly to market signals by just increasing the recovery of the by-product from the main mineral when prices go up and vice versa. For instance, the zinc smelter may be incentivized to recover more germanium from the zinc concentrates (Wellmer et al. 2018).

\footnotetext{
4 This is only a rough calculation to explain the principle, assuming that final products can be produced by a nation. If it exports concentrates, however, the difference would be even larger. The mine would receive only the net smelter return for their concentrates, in the case of zinc normally about $50 \%$ for the gross value used for the calculation above; however for germanium, the mine would receive only a credit in their concentrates (Wellmer et al. 2008) which is far less than the final product value.
}

This, combined with rapid shifts in demand, makes production of by-products much less continuous over time as compared with major metals (Fig. 7). But beyond the ceiling given by the production of the main mineral, there is little room to respond to demand. As shown in Fig. 2, there is, however, no evidence that this inelasticity of minor metals would lead to a disbalanced market in the long term with a sustained price increase when demand increases. The reason lies in the capacity of the demand side to respond to actual or expected supply shortages in a very efficient way via technological change, substitution, and efficiency gains. These responses however can become volatility drivers themselves.

The following sections will not focus on the major metal price swings that go with global economic cycles. It will rather look at the special price peaks or collapses due to technological developments and market speculation, hypes and government interventions, the different elasticities on the demand and supply sides, and the role of substitution. As a general rule, price development is controlled by more than one of these drivers.

\section{The role of substitution}

Minerals with different physical and chemical characteristics go into manufacturing of goods. The demand is therefore not for a material per se, but for its specific function based on the material's physical and chemical properties (Wellmer 2012). 

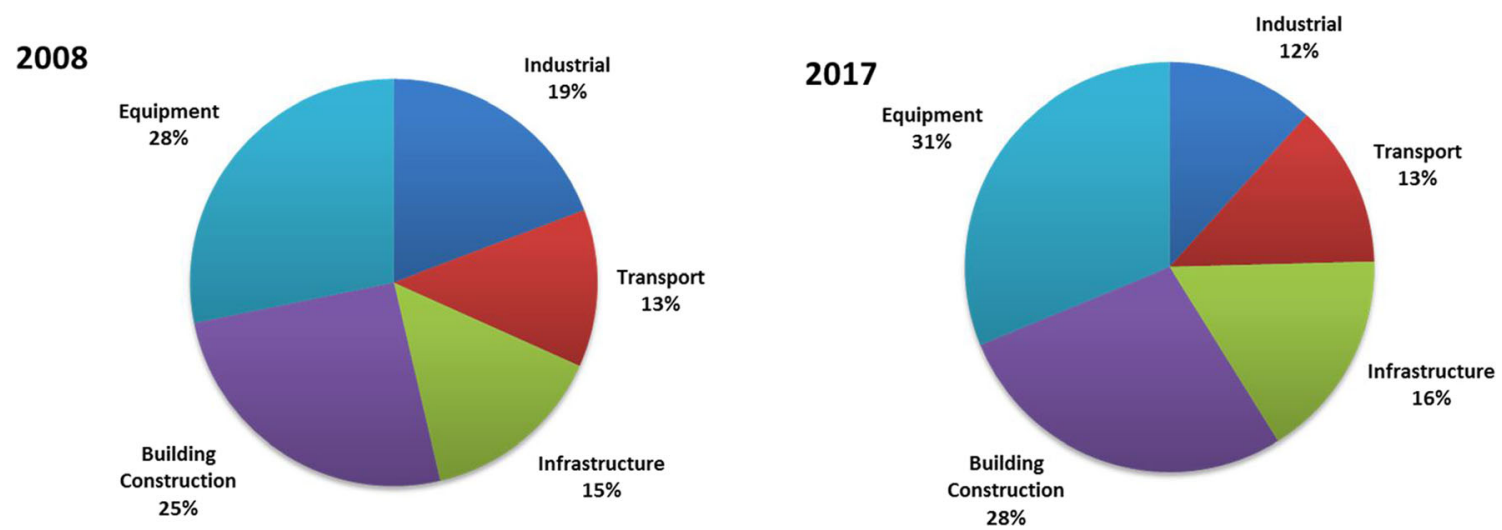

Fig. 5 Usage of copper 2008 and 2017 (sources International Copper Study Group 2007 and 2018)

There is no demand for $1 \mathrm{t}$ of copper, but there is demand for a material with appropriate electrical conductivity for transmitting energy or information. Copper has these characteristics, but there are alternatives. Information can also be transmitted via glass fiber cables, directional antennae, satellite transmission, or mobile phone systems. Substitution can therefore be material (glass fiber vs. copper) or functional (via satellite or mobile phone antennae) (Schebek and Becker 2014).

Each technical solution has its own raw material profile. There are three exceptions to the rule: the nutrient elements nitrogen, potassium, and phosphorous. They are bio-essential and cannot be substituted. The plants need these elements as such. They are as essential as water. Without them, the plants cannot grow. An example that relates to nitrogen is to be discussed in "Rise and fall of the Chilean saltpeter-based economy 1880-1930" section. There are other beneficial elements, micronutrient elements, that support plant growth, but are not necessary for life (Arnon and Stout 1939). These are calcium, sodium, magnesium, sulfur, boron, chlorine, iron, manganese, zinc, copper, molybdenum, nickel, cobalt, and selenium.

Substitution can be considered to be the third column of raw material supply besides primary resources from the geosphere and secondary resources from the technosphere. Commodities regardless of their primary or secondary origin normally have the same value (or related prices if the secondary material has different qualities); both add to supply. The third column, substitution, influences the supply/demand balance not by adding to supply but by reducing the demand as explained above for the functioning of the feedback control cycle of mineral supply. This interaction in a market system with functioning price signals will be shown using the example of iridium and ruthenium on "The platinum group metals" section.
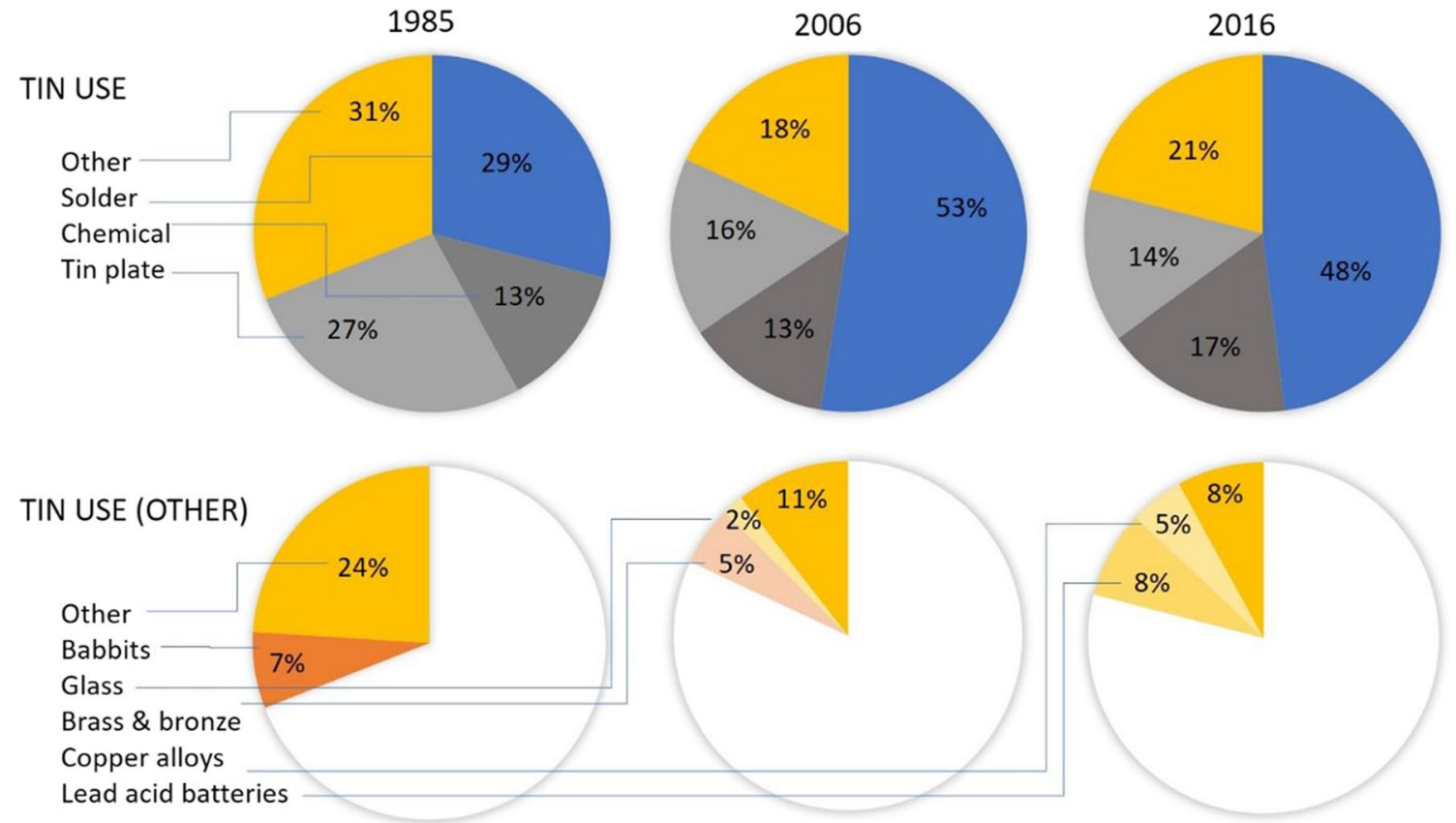

Fig. 6 Usage of tin 2006 and 2016 (ITRI 2007, 2017), 1985 Carlin 1985 
Production fluctuation $1975=100$

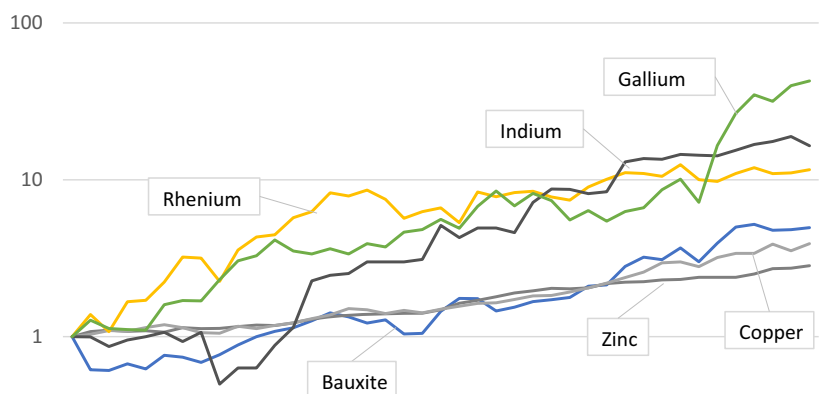

0.1

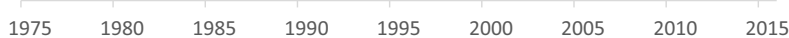

Fig. 7 Relative development of primary production from 1975 to 2015 for aluminum (bauxite), copper and zinc as examples for "normal" major metals and rhenium, indium, and gallium as examples for minor metals (data: Kelly and Matos 2017)

In most of the cases discussed below, technological changes and the new mineral demand patterns that go with it are irreversible. Once demand flips from one mineral to another, market shares are lost and virtually impossible to reconquer. There are cases, however, where substitution seems to be less irrevocable, the most prominent one being the dynamic competition of copper and aluminum for market shares as electric conductor. Copper has more favorable characteristics but is more expensive than aluminum. With advantages on both sides, copper and aluminum have become interchangeable in many applications and are given preference in accordance with their price ratio. Olivares-Galvan et al. (2010) describe this interchangeability in the production of windings for distribution transformers.

However, due to a long-term tendency of an increasing copper/aluminum price ratio since the beginning of the century, copper use for cables and wires fell from almost $100 \%$ to approximately $60 \%$ in 2016 . In the period between 2005 and 2009 , the price ratio increased from 1.2 to 3.5 ; in the same time span, the total amount of copper substituted reached 1.86 million $\mathrm{t}$ (Djukanovic 2016).

\section{Technological change}

\section{Introduction}

As outlined in "Introduction" section, price volatility is driven by discrepancies between demand and supply on the market. The main drivers are technological changes that entail new mineral demand patterns. Ultimately, shifting mineral demand patterns are driven by shifting consumer demand. This has been the case since the early days of humankind, when the first tools where invented. There is however an increasing frequency of new consumer products entering the market.
And there is an ever-higher pace at which these products penetrate the market.

The market penetration of landline phones in Germany took roughly 20 years to reach $90 \%$ of all households (Fig. 9). The cellphone reached that level in half that time. Currently, one out two Germans buy the newest smartphone (Heeg 2019). The consumer's drive to own the latest product, especially high-tech goods, plays a substantial role in an accelerating shift of mineral demand patterns, especially for minor metals. It is to be expected that the number and intensity of demand peaks due to new technologies will increase, not only due to major technological shifts and the increasing pace of technological innovations, but mostly related to a rapidly growing middle class in China and India.

This has consequences for the recycling industry. The recycling industry claims that that the scrap composition, especially from electrical and electronic sources (so-called WEEE), changes so quickly that technological development for optimal recycling with maximum recovery of minor elements can hardly can keep pace (Wellmer and Dalheimer 2012, p. 720).

Although electronic instruments are not material intensive, the sheer size of numbers sold makes this sector a significant raw material consumer. In 2010, Hagelüken and Corti analyzed the situation for mobile phones, personal computers, and laptops including lithium-ion batteries. At that time, 1.3 billion mobile phones were sold and 300 million personal computers and laptops. The raw material consumption of these devices required the following raw materials as percentages of primary production: silver $3 \%$, gold $4 \%$, palladium $16 \%$, copper $<1 \%$, and cobalt $23 \%$. The number of mobile phones and smart phones today are around two billion pieces.

\section{Strontium}

Scenarios that assess technology developments and demandside trends, therefore, are very important for evaluating the future raw material requirements. However, changes in demand are increasingly difficult to predict because of the shorter production cycles, as demonstrated in Figs. 8 and 9.

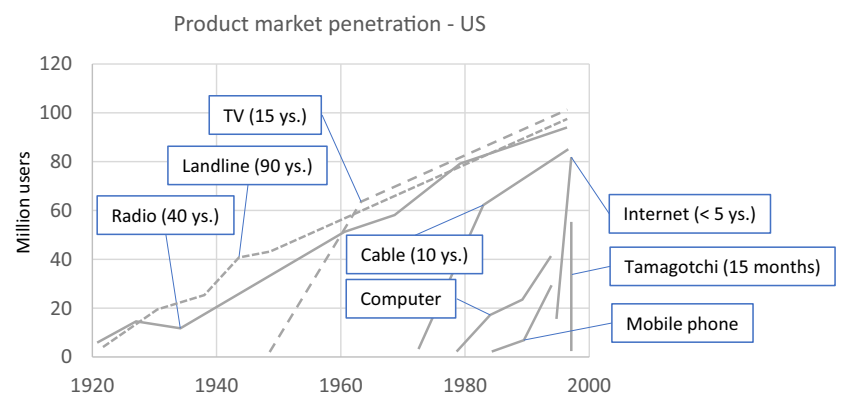

Fig. 8 Market penetration times of selected products on the US market 1922-1996 (modified after Berner 2000) 
Fig. 9 Gadgetry market penetration and technologies in Germany 1962-2015 (data: Destatis.de 2017)
Product market penetration

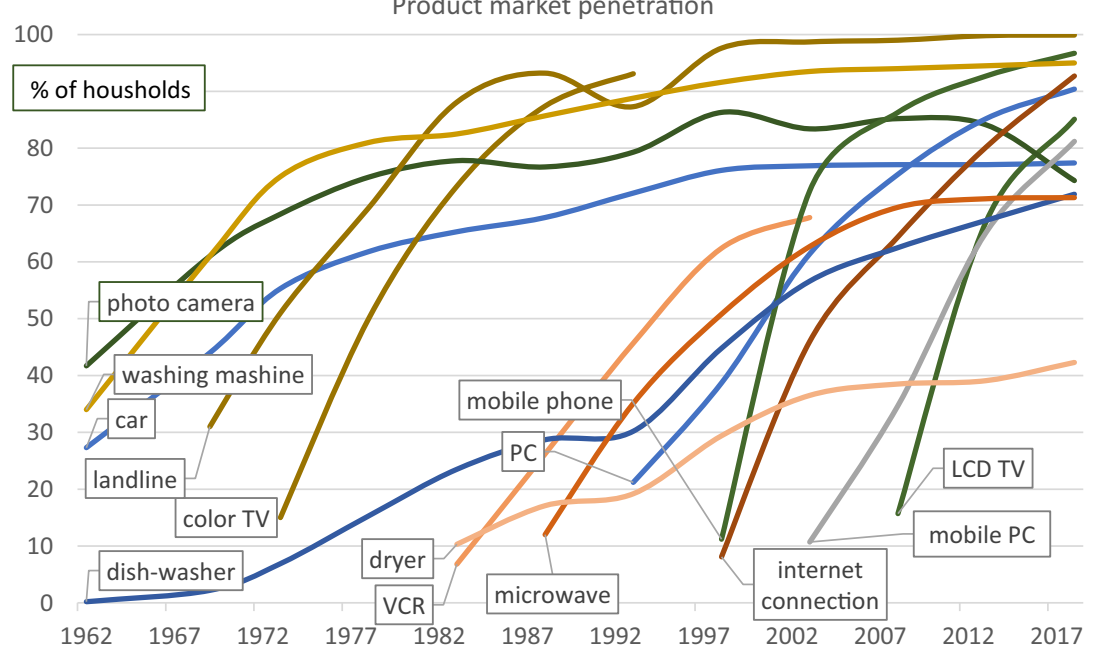

The transition to flat TV/LCD and plasma (Fig. 10) materialized within only 2 years and had substantial impact on the demand of several metallic raw materials.

Strontium production collapsed in the first decade of the new millennium (Fig. 11). Within 2 years, production was nearly halved. In $2006,75 \%$ of strontium production came from developing nations (Ober 2007).

This rapid market collapse was caused by the transition from classical ray tubes to LCD screens (Fig. 10). This transition occurred within only 2 years from 2006 to 2007. The glass of a classical cathode-ray tube contained lead (in the throat and funnel sections) as a protection from X-ray radiation and barium and strontium in the screen itself. After the introduction of today's LCD flat screens, these elements were no longer required, as the TV glass substrates of the modern

\section{LCD vs. CRT TV shipments}

\section{$100 \%$}

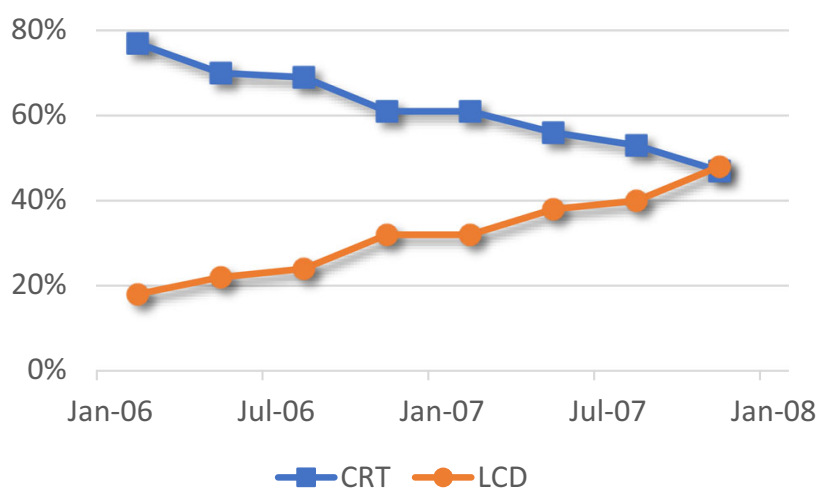

Fig. 10 Changeover in technology in TV screens from cathode ray tube (CRT) to liquid crystal display (LCD) 2006 and 2007 (Murph 2008, with kind permission from Darren Murph) displays consist of alumino-borosilicate. However, the technology transition to modern displays has resulted in a new dependency on indium and tin, required for the transparent ITO (indium tin oxide) layers that function as electrodes in the displays (Wellmer et al. 2018).

Figure 11 resembles a "Hubbert" curve, with a rising, peaking, and subsequently declining production. Hubbert curves for production have been frequently used in an attempt to predict depleting resources and, as a consequence, supply shortages, the most prominent one being peak oil and peak phosphate (Wellmer and Scholz 2017).

As is obvious, this is a demand-driven peak curve which has nothing to do with shortages of supply. It is shaped by rising and falling demand like, e.g., peak asbestos due to environmental restrictions. Many commodity production analyses lack the distinction between supply and demand-driven peak curves and produce forecasts of somewhat limited benefits (Scholz and Wellmer 2013). Another case of a demanddriven production curve will be discussed for the raw material natural nitrate in "Technology uncertainties and substitution

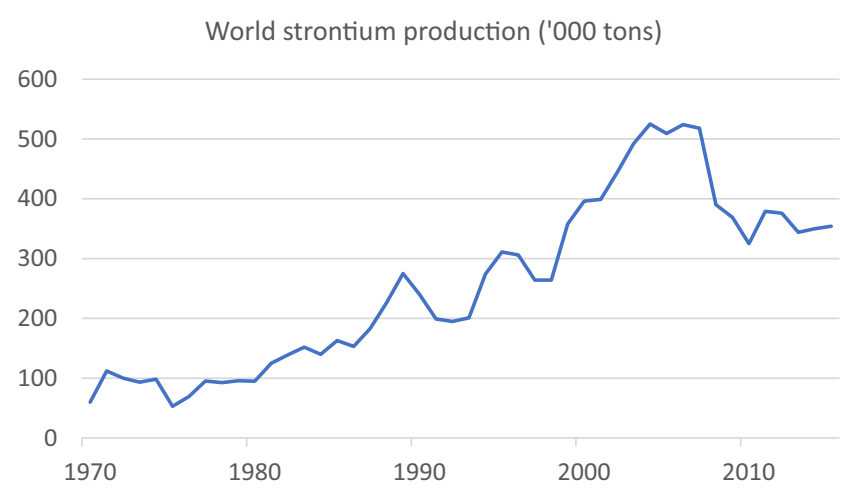

Fig. 11 World strontium production 1970-2017 (data: USGS Historical Statistics 2019) 
options in energy technologies" section. Both indicate that producing countries, when forecasting their production, not only must consider reserves and resources but also the demand side, specifically the market possibilities. The country perspective is discussed in detail in "The producing countries' perspective - two case stories" and "Implications for producing countries - the road ahead" sections.

\section{Germanium}

Germanium and gallium stand for rapid changes in the usage of minor metals within decades. From 1948 until the 1970s, germanium transistors played a vital role in solid-state electronics. However, from 1965/1970, germanium was continuously substituted by electronic grade silicon and prices collapsed. New applications arose in the late 1950s with the boom in nuclear physics that produced a demand for special applications such as military and aerospace, yet with a market much smaller than mass products (Schwarz-Schampera 2014b).

Fiber and infrared optic industry (night vision systems) created a new market and substantial demand for germanium and other minor metals at the end of the 1990s (Melcher and Buchholz 2014; Buchholz et al. 2019). As reflected in Fig. 12, over the past two decades, the major uses for germanium changed from dominantly infrared optics in 1990 to fiber optics in 2000 and new applications for polymerization catalysts as in PET bottles. Relative proportions of these three applications have continuously changed over the years without showing a major trend (Melcher and Buchholz 2014). There are regional differences in usage. Fiber optics are the main use in the USA ( $42 \%$ of global usage) and EU (21\%) followed by
Asia Pacific (12\%). The polymerization catalyst sector is unimportant in the USA and Canada, but important in Europe (29\%), Asia-Pacific (25\%), and Japan (21\%) (Global Industry Analysts Inc 2010).

The boosted germanium demand and increased production were however not prompted by soaring prices (Fig. 12). Germanium, as discussed in "Demand-side-driven volatility" section, is a by-product of zinc mining. Production most probably was increased by just ramping up refining capacity and processing the already available concentrates. It is to be expected that once germanium production reaches the ceiling given by available zinc concentrate supply, prices will soar, at least temporarily.

\section{Gallium}

As germanium, gallium is a semiconductor. According to Butcher and Brown (2014), the greatest consumption currently is in gallium arsenide (GAAS) compound semiconductors. Compound semiconductors, in particular GAAS semiconductors, can provide a number of advantages over other semiconducting materials, for example, silicon. In integrated circuits for high-frequency components, for example, GAAS is significantly more efficient as a substrate than silicon. Not only is it faster than silicon (the electrons travel faster than in silicon), but it can also operate over a much wider range of temperatures (Butcher and Brown 2014).

Today, the major use of gallium is in high-frequency components for integrated circuits, and the second largest sector is in light-emitting diodes (LEDs). The consumption for this usage grew substantially in the past decade for optoelectronic
Fig. 12 Usage and price trends of germanium 1990, 2000, and 2010 (Wellmer et al. 2018, based on Melcher and Buchholz 2014)

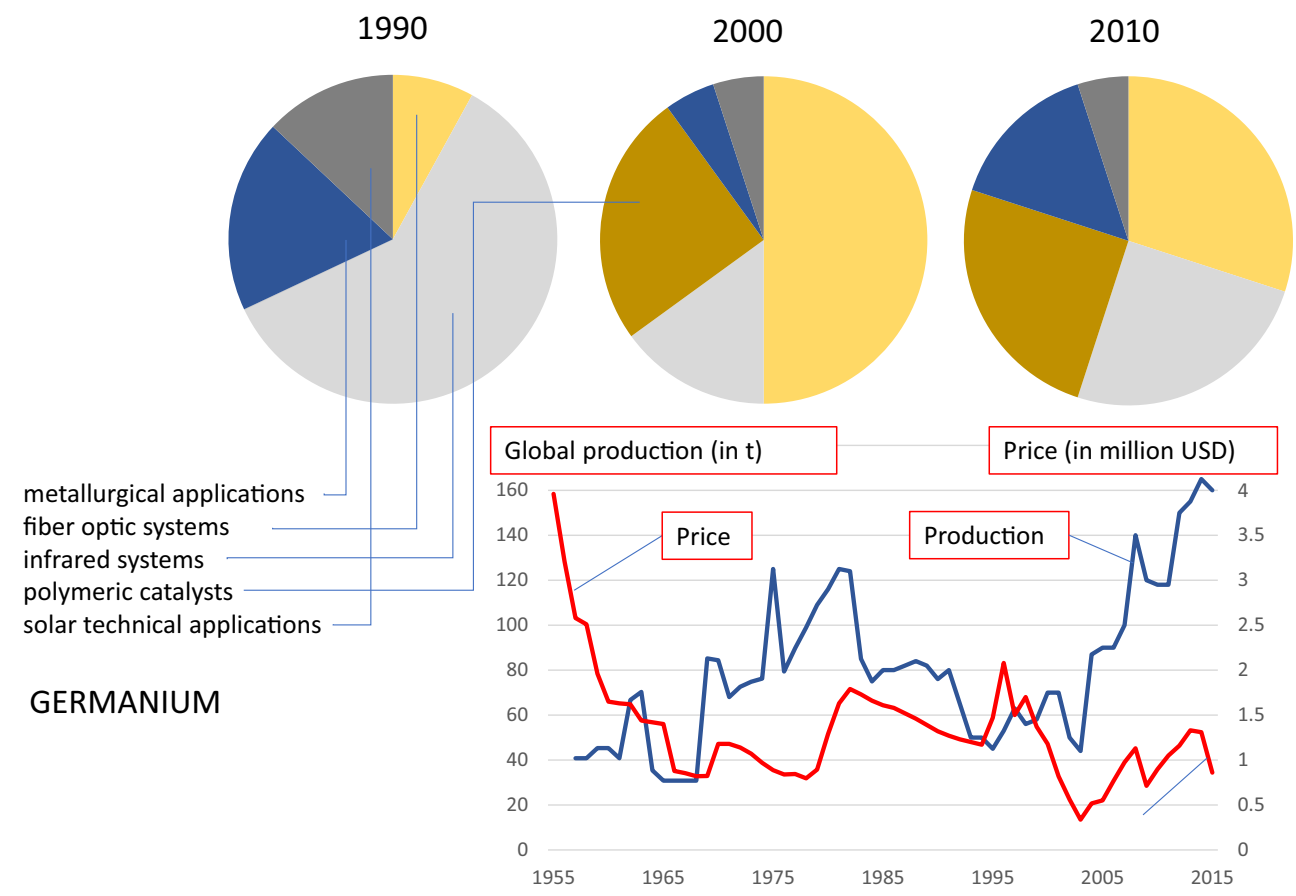


and microelectronic industries including integrated circuits (ICs) for smartphones, LEDs, or high-power transistors. It is expected that in the medium term, consumption of gallium will grow due to larger use in thin film photovoltaics and the upgrading of the mobile phone systems for the newest generation $5 \mathrm{G}$, the basis for autonomous driving or the internet of things (Liedtke and Huy 2018). The price-production pattern is similar to germanium (Fig. 13).

\section{The effect of coupled products on volatility}

\section{Introduction}

As explained in "Introduction" section, coupled elements occur in families like the platinum group metals (PGMs) and the rare earth elements (Wellmer 2008). The REEs or lanthanides are a group of 15 elements such as europium, samarium, cerium, dysprosium, or neodymium, used in a wide range of applications from catalysts to permanent magnets or superconductors. In addition, yttrium, although not a REE, is a "coupled element" of the REE family because it typically occurs in combination with the REE. The PGMs comprise the light platinum metals ruthenium, rhodium, and palladium and the heavy platinum metals osmium, iridium, and platinum and have their main importance as catalysts in the chemical and in the automotive industry for the cleaning of exhaust emissions. The coupled elements lie closely together in the periodic table of elements. They are chemically similar and are therefore co-precipitated in the ore-forming processes. As a consequence, they are found, mined, and processed together. Each ore or ore deposit has a typical ratio for each element in the family (Nassar et al. 2015). In general, there are no main elements as in the case of byproduct elements; however, for the PGM, a certain portion always is a by-product of nickel mining.

Balance problems are typical for coupled elements. Each element is produced in different quantities determined by the characteristics of the ore deposits and seldom in agreement with the quantities required by the market (Kesler 1994). In consequence, there are only one or few elements that are "drivers" for the production level of one family, such as platinum for the PGM. In the REE case, it first was europium (required for color TV screens as described above in "Strontium" section), then samarium or cerium; today, it is mostly a neodymium/praseodymium mixture and dysprosium, due to the push for renewable energies, and terbium. Neodymium/praseodymium and dysprosium are the preferred solutions for permanent magnets for offshore windmills. The remaining REE production can only be sold in smaller quantities and at low prices or be stockpiled. The REEs are discussed below in section "Rare earth elements (REE)". In the PGM group, the main metals used are platinum, palladium, and rhodium (Hagelüken 2005). The other metals ruthenium, osmium, and iridium normally have a rather limited market; for osmium, there are no noteworthy industrial applications (Schmidt 2015). In the smelting and refining process, they are separated only at the end of the metallurgical process. Those quantities that cannot be sold are stored as "intermediates" and only processed further to marketable products if a sudden demand arises (Renn et al. 2017).
Fig. 13 Usage of gallium in the US (data: USGS Historical Statistics 2019, Foley et al. 2017; Liedtke and Huy 2018)

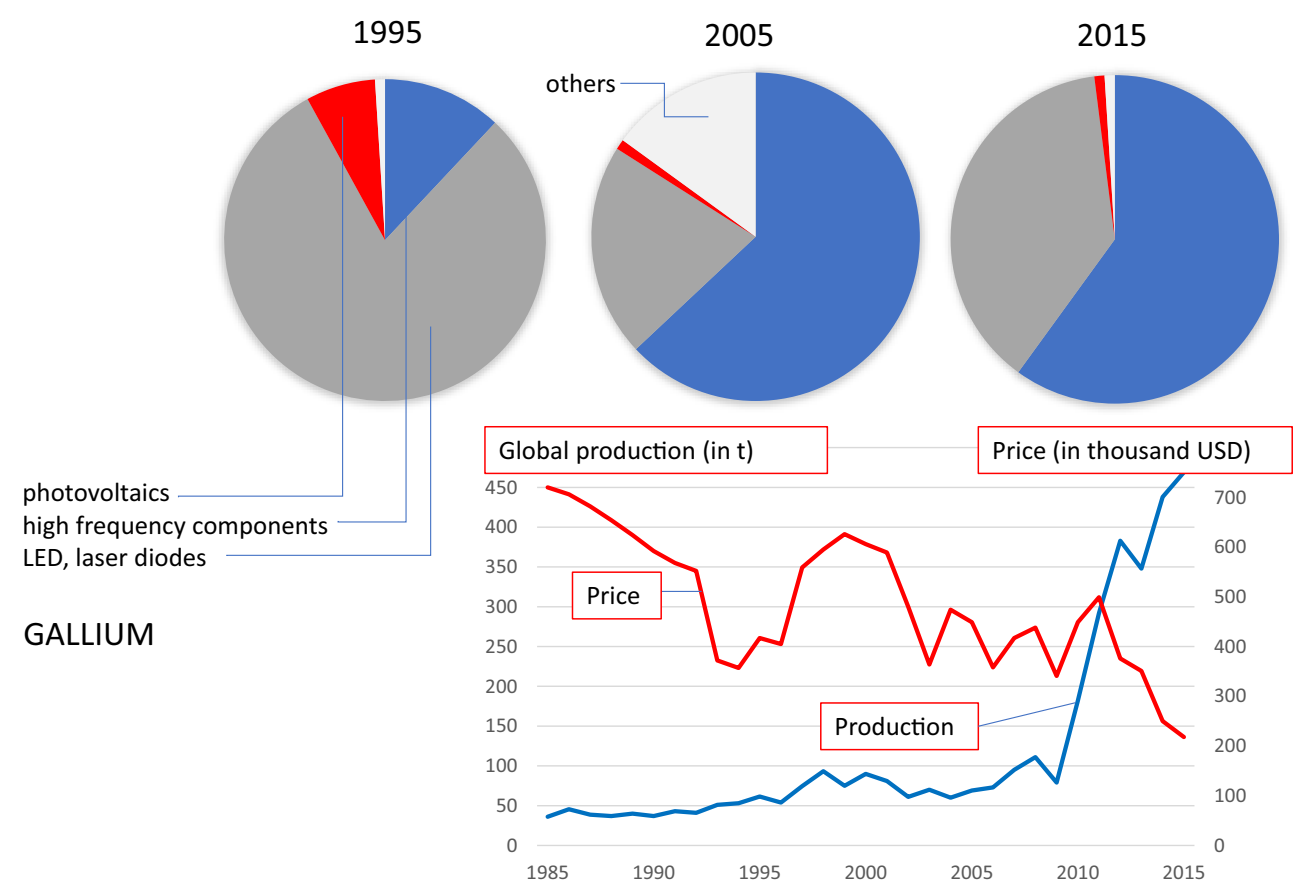


Fig. 14 Palladium and platinum price going in opposite directions was accelerated due to the diesel scandal and the subsequent drop in demand for platinum, that preferred metal used in diesel catalytic converters (data: S\&PStandard and Poor's market intelligence 2019)
Palladium and Platinum prices (USD /oz)

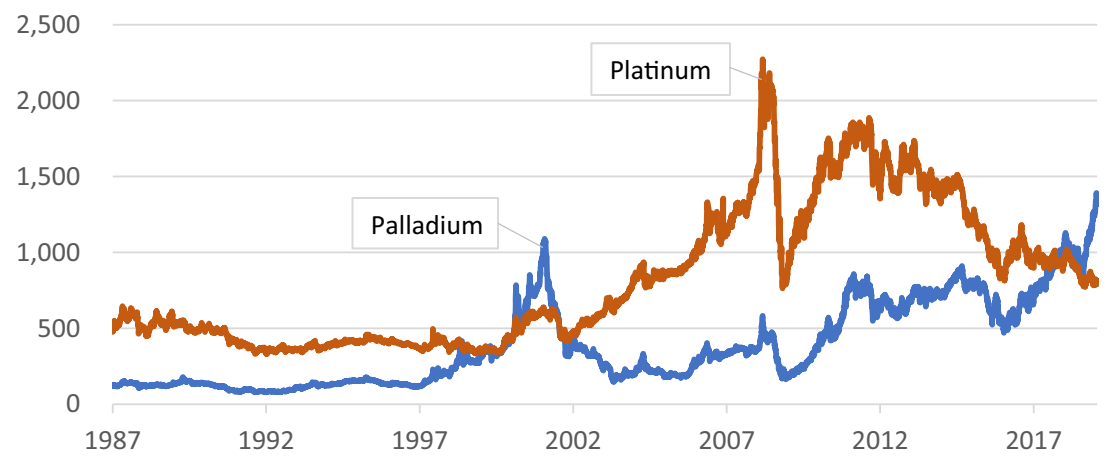

\section{The platinum group metals}

In the PGM family, the price relationship between platinum and palladium is a good example of how the balance constraints of coupled elements cause price peaks due to changes of demand in the context of technological development. Until recently, the platinum price was always higher than the palladium price. However, the development of platinum and palladium prices strongly follows technological trends in the automotive sector (Buchholz et al. 2019). Platinum is used for catalytic converters in diesel cars and palladium in gasoline engines. Since the diesel scandal, ${ }^{5}$ prices for palladium have almost doubled and are still rising, whereas the platinum price is falling continuously (Fig. 14). Today, palladium has taken the driver's seat. Any new political decisions regarding the future of diesel cars and consumer behavior will affect the markets for both metals.

The 2000/2001 palladium price peak was caused by export restrictions in Russia, the dominant producer (48.5\% in 2000) (Hagelüken 2005). Volatility caused by government interference will be discussed in detail in "Volatility prompted by government regulations - vanadium" section.

The PGM iridium and ruthenium with a much smaller production volume than platinum and palladium (2017 platinum $190 \mathrm{t} / \mathrm{a}$, palladium $200 \mathrm{t} / \mathrm{a}$, rhodium $35 \mathrm{t} / \mathrm{a}$, ruthenium $39 \mathrm{t} / \mathrm{a}$, iridium $8 \mathrm{t} / \mathrm{a}$ ) provide more examples for the interaction of coupled products and their markets: Prices for ruthenium and iridium are significantly lower. Therefore, manufacturers sometimes attempt to substitute at least part of the normally much more expensive PGM platinum, palladium, or rhodium, with the cheaper iridium or ruthenium. The very limited supply of the latter, however, produces immediate price reactions, as happened in 1996. Until May 1996, the iridium price fluctuated around US\$60/oz. When Mitsubishi introduced a catalyst for gasoline direct injection (GDI engines) containing iridium alongside platinum and rhodium, the price for iridium

\footnotetext{
${ }^{5}$ In 2014 onwards, software in diesel cars which manipulated air pollution tests was discovered in vehicles from many major car makers; this led to a substantial slump in diesel car demand.
}

increased tenfold (Fig. 15) within a year due to constrained supply. It found a plateau around US $\$ 400 / \mathrm{oz}$ until the end of 2001, when the catalyst was phased out (Hagelüken 2005, 2018).

The second example is ruthenium. The normal usage of ruthenium is in the field of superalloys for aircraft turbines, electronics, catalysts, and fuel cells (Hagelüken 2018). Late in 2006, ruthenium found a new application in hard disk drives (Nassar et al. 2015). Due to the limited possibilities of rapidly increasing supply caused by the effect of coupled products, a shortage developed immediately, and prices skyrocketed. The price, having been at US $\$ 90 / \mathrm{oz}$ prior to the peak rose almost tenfold in late 2006 (Fig. 16).

Prior to 2006, there was no ruthenium recycling. The price peak sparked investment in recycling facilities. Secondary ruthenium came on stream and provided increasing supply which in turn put pressure on the prices (Hagelüken and Meskers 2010). This is a good example how the feedback control cycle of raw material supply, explained in the "Introduction" section, also works with by-products and coupled elements.

\section{The effect of hypes}

Volatility can be caused or exaggerated by targeted speculation or hypes generated by market participants. Hypes develop from price increases or even only from a market sentiment that then is exaggerated. Hypes can be triggered by demand from non-industry "investors" or "speculators" who believe that the price is going to rise further and demand from industry users who buy for "precautionary" reasons, either because they fear that the price is going to rise further, thus reducing their competiveness, or because there is a risk of physical shortage, which might force them to reduce production. Both causes interact and overlap. Only insiders will be able to decipher the exact causes. Good examples are the tantalum price peak at the end of the 1970s and the REEs boom 2010/2011, described below. Inversely, hypes can also be triggered by a targeted speculation. This was the case with the silver hype 


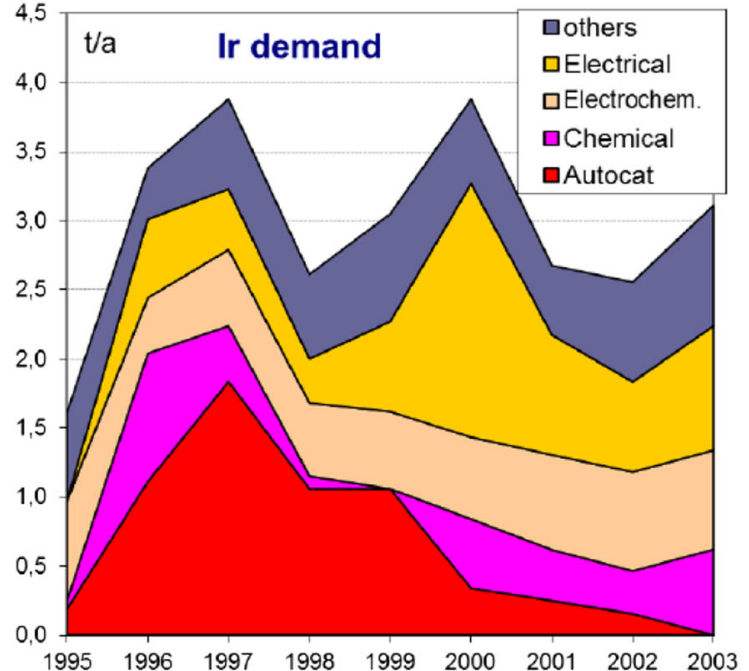

1996: Mitsubishi introduced Ir-catalyst for GDI-engine (only in Japan)

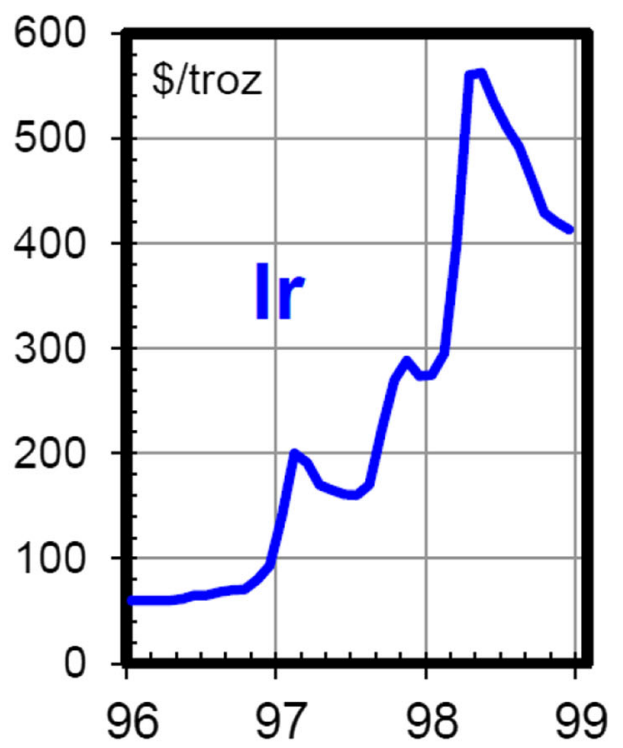

Further Ir price development: 11/2003: 75 \$; 4/12 - 4/13: > 1000 \$; 11/16: 700 \$/troz

Fig. 15 Iridium usage and price (Hagelüken 2005, 2018). The graph on the left shows the new demand for iridium created by introducing an iridiumbased catalyzer for the Japanese market. Due to the small iridium market, the price reaction was violent (with kind permission of C. Hagelüken 2018)

of 1980, described in "Targeted market speculation: the 1980 silver Saturday" section.

\section{Tantalum}

At the end of the 1970s, the conventional wisdom in the market was that tantalum, necessary for capacitors required in every electronic circuit, would become scarce. This presumed scarcity created a hype with a significant price peak (Fig. 17). After the hype was over, market insiders acknowledged that there had been no shortage at all. In fact, tantalum was available as needed. Market opinions can quickly turn into self-fulfilling prophecies, following the theorem of Thomas and Thomas (1928): If a situation is believed to be real, the consequences of that imaginary situation can become real. A presumed shortage can trigger hoarding, creating a factual shortage. This was

Ruthenium price (USD/oz)

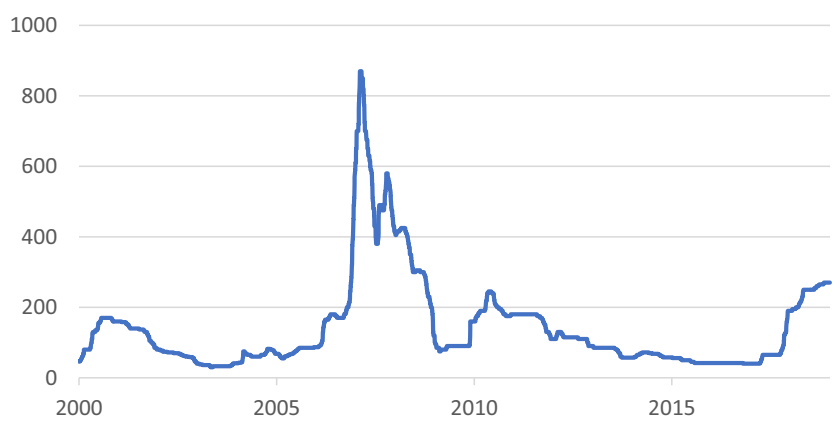

Fig. 16 Ruthenium price 200-2019 (Johnson Matthey base price, data: Johnson Matthey) the case during the tantalum peak (Wellmer and Hagelüken 2015) and has been discussed for oil in the early 1970 s (Tilton 2003). Kilian 1 (2009) studying oil price shocks calls this kind of price peak "precautionary demand shock" in contrast to "oil supply shocks" and "aggregate demand shocks."

Regardless if a shortage is real or presumed, the price peak triggers the feedback control cycle of mineral supply described above ("Demand-side-driven volatility" section). In this case, the reaction was very quick on the supply side. At that time, about $50 \%$ of tantalum came from the mining of columbite-tantalite ores (Coltan) in Australia and Africa and about 50\% from tin slags in Malaysia and Thailand. During periods of unattractive prices, many of these tin slags were too low grade to be processed for tantalum. They were used for landfill to build roads and houses. During the tantalum boom, these slags were uncovered as readily available tantalum source, taken up again and reprocessed, thereby using unconventional ways of "mining" even on shopping or recreational properties. At the beginning of the new millennium, another tantalum price peak occurred (Fig. 17) during the IT boom followed by the hype of the dotcom bubble (Damm 2018).

\section{Rare earth elements (REE)}

In 2010, China controlled more than $95 \%$ of global REE production. In an attempt to crack down on illegal REE mining, China cut back its REE production and reduced its export quotas by a significant $40 \%$ (Fig. 18). What happened then illustrates how speculation is triggered by a government's market intervention. 
Fig. 17 Tantalum nominal and real prices from 1965 to 2015

(data: USGS Historical

Statistics 2019)
Tantalum price and production

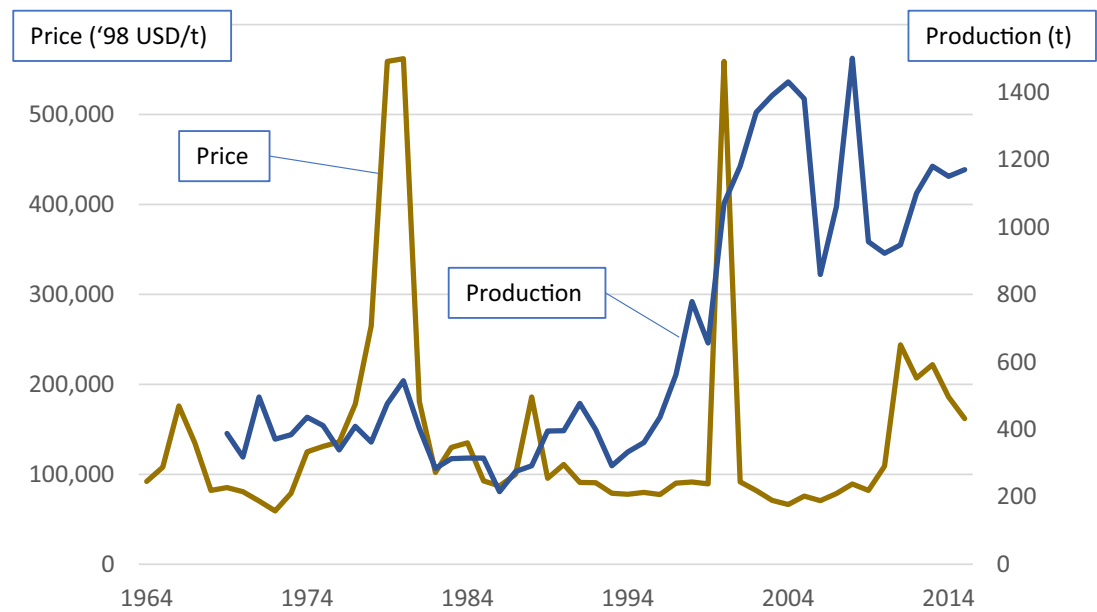

Export quotas produced an anticipated shortage, and prices skyrocketed. Speculation further boosted the price increase. For a short period during 2011, the dysprosium price was a hundred times higher than the plateau price phase in 2002/2003. It took about 2 years for the market to return to normality. A noteworthy detail is that speculation had not started earlier, since the first significant export quota cut happened already in 2008 and the second in 2010 (Fig. 18). The reason is that after the 2008/2009 financial crisis, the global economy recovered, and raw material prices peaked again in 2011.

The collapse of the REE price bubble had several reasons: Demand was in effect not as high as speculators had anticipated. At the same time, production outside of China increased slowly but steadily. In China, on the margins of official production, a still significant amount of illegal REE mining, estimated to be as high as $40 \%$ of the Chinese official REE production (Packey and Kingsnorth 2016; Kingsnorth 2018), continued to supply the markets. And lastly, material savings and substitution effects played a significant role in the normalization of the markets. By 2017, the Chinese share of world production had decreased to about $80 \%$ (Gambogi 2018).

Material savings have for instance been achieved in permanent magnets, where a previous amount of 6 to $8 \%$ dysprosium was brought down to $1 \%$ or less without performance losses (Elsner 2012). Today, in LEDs and energy-saving lamps, material intensity of yttrium and the heavy rare earth elements europium and terbium per luminous flux unit is 15 to 20 times lower (Kingsnorth 2015).

Substitution can also be obtained via functional substitution (Halme et al. 2012; Schebek and Becker 2014): by replacing permanent magnets in synchronous motors with induction motors, for example, or by employing ferrite motors that do not require rare earth elements.

The REEs are a good example not only for volatility exaggerated by a hype - leading to overheated speculation - but also for volatilities created by indirect subsidies via environmental dumping, monopoly building, and market intervention.

And since the reduction of the export quotas never really led to a physical shortage, it may also be fair to say that the price
Fig. 18 REE production and prices (source: BGR data base 2018)

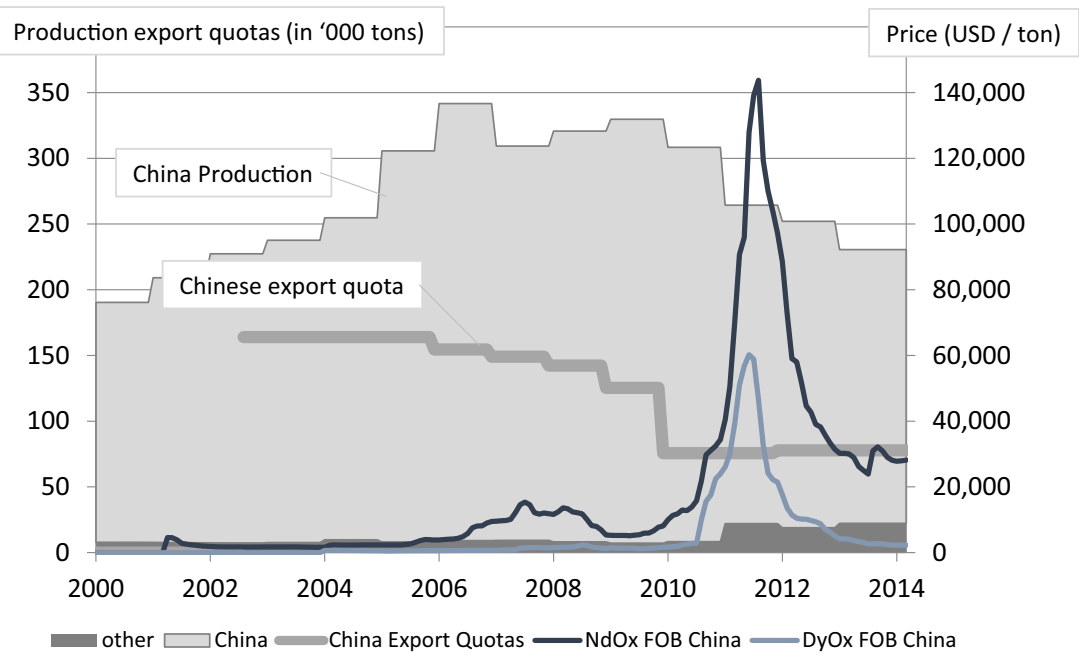


Fig. 19 Annual mine production of rare earth oxides (REOs).

(Haxel et al. 2002; Liedtke and Elsner 2009)

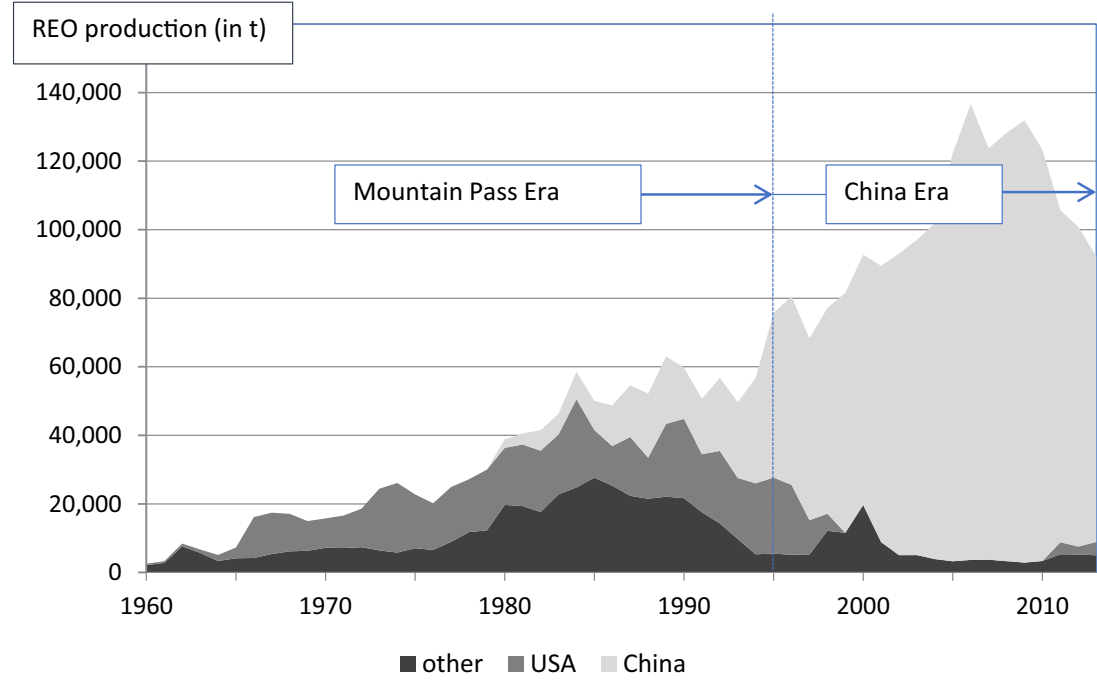

increases were a reaction to a perceived rather than to an actual shortage, as in the case described in "Tantalum" section (Fig. 19).

The virtual monopoly established by China in the mid-1990s was not based on competitiveness or reserves/resources not being available outside of China (Hedrick 2010; Wall 2014), but on indirect subsidies. China controls the largest REE deposit of the world, the Bayan Obo deposit in Inner Mongolia (Wall 2014) where the REEs are contained in bastnaesite, which is mined as a by-product in iron ore mining. In addition, another significant source of especially heavy REE from China is ion adsorption deposits in which the REEs occur in clays (Wall 2014).

The competition between the Mountain Pass - the only US producer - and the Chinese production took place under unequal social and environmental standards. The Mountain Pass mine had to close in 2002 due to the strict environmental laws in California which Mountain Pass could not or was not willing to comply with. Once dominating the market, China imposed export quotas from 2006 (Table 1) onwards, resulting in price hikes and increased volatility. Recent evidence indicates that the Chinese government is increasingly raising its environmental standards (Schüler-Zhou 2018).

\section{Targeted market speculation: the 1980 silver Saturday}

In the case of the REE discussed in section "Rare earth elements (REE)", the expectation of a shortage was triggered by the tightened Chinese export quotas whereas tantalum ("Tantalum" section) price volatility had its origin in a mere assumption among peers concerned with raw material supply. In contrast, the silver hype in 1979/1980 can be traced back to an active intervention of known individuals, two billionaire investors, the Hunt Brothers from Texas and their partners. Its effect was a temporary but significant price volatility (Fig. 20).
Table 1 Development of Chinese export quotas (Kingsnorth 2013, 2018)

\begin{tabular}{lllll}
\hline Year & Export quota (t) & $\begin{array}{l}\text { Change compared to year } \\
\text { before }(\%)\end{array}$ & $\begin{array}{l}\text { Estimated need outside of } \\
\text { China }(\mathrm{t})\end{array}$ & $\begin{array}{l}\text { Export from } \\
\text { China (t) }\end{array}$ \\
\hline 2004 & 65,609 & & 53,000 & 67,171 \\
2005 & 65,680 & 0 & 51,000 & 62,922 \\
2006 & 61,070 & -7 & 51,000 & 60,270 \\
2007 & 59,643 & -2 & 42,000 & 49,484 \\
2008 & 49,990 & -16 & 51,000 & 51,916 \\
2009 & 50,146 & 0 & 26,000 & 40,025 \\
2010 & 30,258 & -40 & 49,000 & 35,000 \\
2011 & 30,246 & 0 & 35,000 & 15,382 \\
2012 & 30,996 & +2 & 39,500 & 14,845 \\
2013 & 30,999 & 0 & 37,500 & 18,816 \\
2014 & 30,610 & -1 & 44,000 & 24,166 \\
2015 & Cancelled & - & 49,000 & 24,166 \\
& Jan. 2015 & & & 30,711 \\
\hline
\end{tabular}


Silver price (USD/oz)

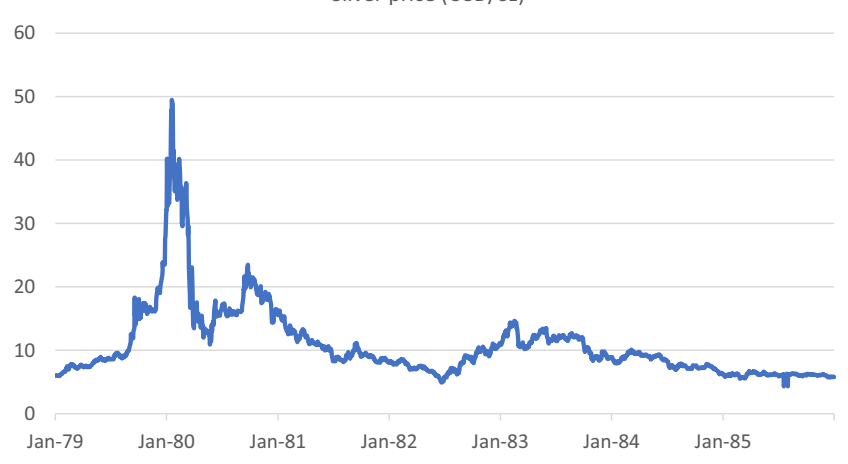

Fig. 20 Silver price volatility produced by the Hunt brother's attempt to corner the silver market. The scheme toppled, and the price collapsed when the commodity exchange changed the exchange rules (data: S\&PStandard and Poor's market intelligence 2019)

The silver price jumped within a year from about $6 \mathrm{US} \$ / \mathrm{oz}$ on January 1, 1979 to nearly US\$50/oz in January 1980. The Hunt Brothers tried to corner the market by physically buying silver and simultaneously acquiring contracts for future delivery and betting on ever-increasing prices. In total, the Hunt brothers bought close to $4.500 \mathrm{t}$ of physical silver and about $6.200 \mathrm{t}$ of future contracts. It was estimated that the group held about one third of the entire world supply of silver (other than that held by governments).

In response to the scheme, the commodity exchange (COMEX) changed the exchange rules and the plot toppled. The silver price collapsed on March 28, 1980, "Silver Thursday" (Fay 1982). Subsequently, the silver price settled first around US\$15/oz and later around US\$5/oz, where it remained for about 20 years. Although the Hunt Brothers symbolize the silver hype, the price rally has also to be seen against the background of the financial uncertainty in the 1970s caused, for example, by the two oil crises in 1973 and 1979, wars (aftermath of the Vietnam war, Jom-Kippur war, Afghanistan war of the USSR), and the high inflation rates. This economic environment induced a flight into precious metals, predominantly gold, causing an enormous demand for gold. At the same time, between 1971 and 1973, the then fixed gold price was raised several times from US\$35 to US\$43. Eventually, in 1973, it was allowed to float freely and jumped up to US\$850 in 1980 (Wellmer and Scholz 2017). Silver usually follows suite. In normal times, the ratio to the gold price ranges between 50 and 80 (Green 1999).

\section{War and civil crises as volatility driver-cobalt}

War and civil unrest can falter mineral production and trade and produce shortages on the supply side and price peaks on the market. As described in "The role of substitution" and "Rise and fall of Chilean saltpeter-based economy 18801930 " sections, this volatility can trigger the feedback control system for raw material supply and start a substitution process.
Substitution of a mineral means a loss of market shares, mostly irreversible, even if a material had been considered impossible to substitute. A constraint on the supply side thereby produces a reaction on the demand side with a deeper and longer lasting effect on the market.

A good example is the case of cobalt and the 1978 Shaba crisis in the Democratic Republic of Congo (formerly Zaire), the main supply country for cobalt. The publication of "Limits to Growth," a report issued for the Club of Rome (Meadows et al. 1972), increased the sensitivity in political circles for potentially critical raw materials. Most industrialized nations initiated studies by their earth science and/or economic research organizations about the exposure of their national economies to supply risks (Wellmer and Schmidt 1989). Cobalt was rated as critical and strategic because substitutes were thought to be unavailable and cobalt hardly recyclable (BGR, DIW 1997). This assumption, however, did not account for the dynamics and learning effects in a situation of serious supply shortage. The cobalt price spiked due to supply interruptions caused by civil unrest (Fig. 21). Soaring prices triggered research and within little time new materials replaced cobalt in areas where it previously was considered to be irreplaceable. In permanent magnets, ferrites took a significant market share away from cobalt (Fig. 21). Prior to the price peak, 30\% of cobalt went into the market of permanent magnets; after the crisis and the loss of market shares to ferrites, the share had fallen to only $10 \%$. As for any other cases, this loss was irreversible (Wellmer and Hagelüken 2015). What had started as a brief supplydriven shortage and volatility entailed a reaction on the demand side that was far more lasting.

\section{Volatility prompted by government regulations-vanadium}

The case of REE in section "Rare earth elements (REE)" is already a good example how government intervention in production and export quota started a hype and triggered volatility. Another example is vanadium (Fig. 22) showing extreme volatility with eightfold to tenfold price peaks in recent times. Vanadium is used primarily in the production of steel alloys mainly for high-strength, low-alloy (HSLA) steel. The addition of small amounts of vanadium, often less than $0.1 \%$, to an ordinary carbon steel can significantly increase its strength and improve both its toughness and ductility. HSLA steel is attractive for high-rise buildings, bridges, pipelines, and automobiles because of the weight savings obtained (Kuck 1985). Other usages are as a catalyst for the chemical industry; in the making of ceramics, glasses, and pigments; and in vanadium redox flow batteries (VRBs) for large-scale storage of electricity (Fig. 23) (Kelley et al. 2017). The vanadium redox flow battery uses the ability of vanadium to exist in solution in four different oxidation states and uses this property to make a battery that has just one electroactive element instead of two. 
Fig. 21 Cobalt: mean annual prices in US\$/lb and consumption in Western World by main uses (from Wellmer (2008) and Wellmer and Hagelüken (2015), with permission from Schweizerbart)

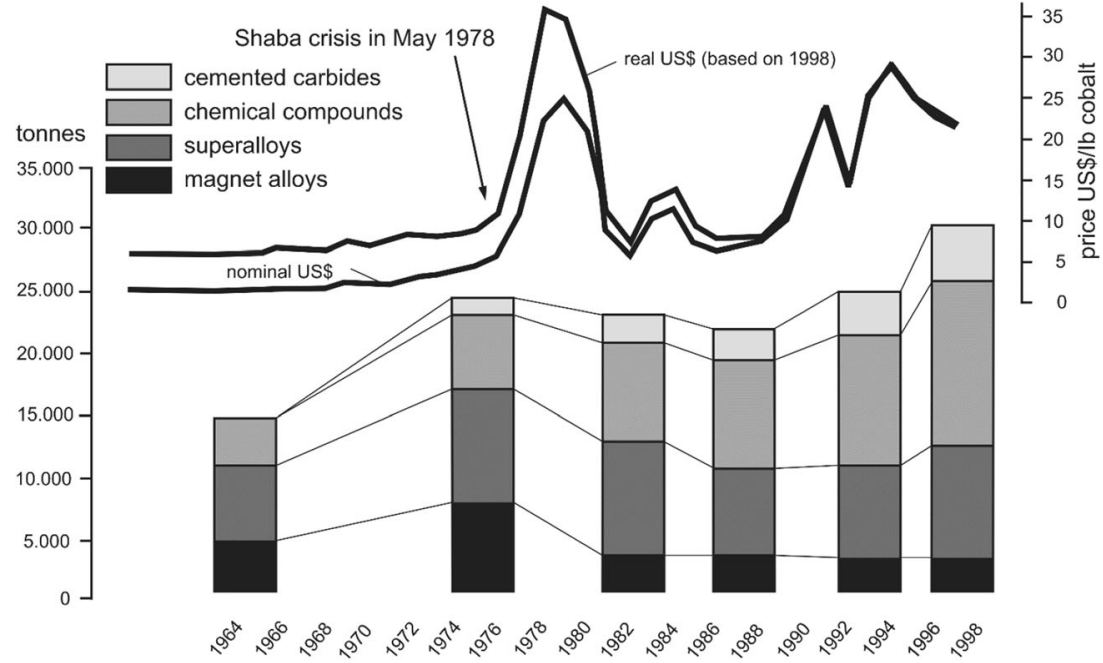

The current high price has its origin, quite comparable with the REE situation described above, in tighter environmental regulations in China that forced several producers to cease production. In 2016, when the Chinese share of world production was 55\%, the Chinese government stopped imports of vanadium in slags - which is the most important basic material for vanadium production - and of vanadium in scrap. The import ban on waste is part of the country's ongoing effort to curb pollution. To ensure domestic supply, the Chinese government imposed a temporary ban on the export of vanadium pentoxide (DERA 2018).

Then in November 2018, the Chinese government created an additional domestic demand for vanadium by setting a new standard for high-strength rebar steel used in construction (DERA 2018). The law requires that rebar manufacturers use more vanadium to reinforce the steel. This was a consequence of the devastating performance of Chinese housing construction in powerful earthquakes, particularly during the 2008 earthquake in Szechuan province that killed an estimated 90,000 people (Treleaven 2019). Additional demand was generated when Japan ruled on increased vanadium in steel rebar

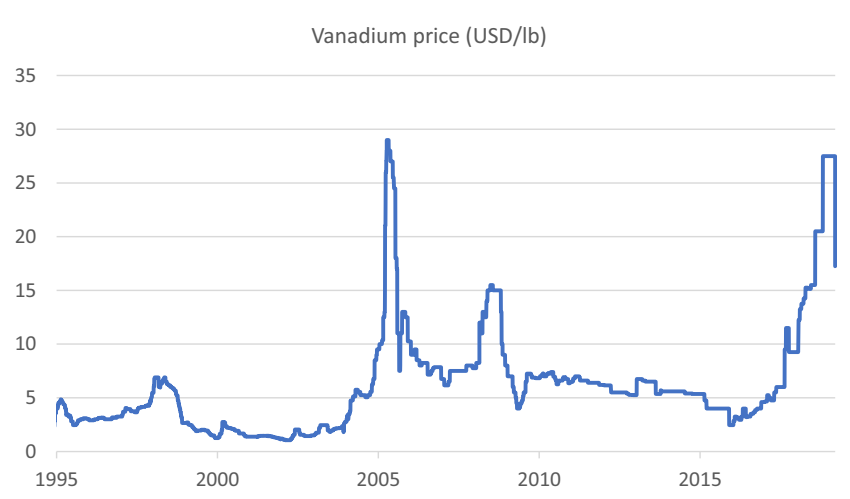

Fig. 22 Vanadium price volatility prompted by Chinese government intervention (data: S\&P market intelligence) to meet quality standards of other major steel-producing countries (Kelley et al. 2017).

There are two other effects that could have contributed to the volatility:

(a) There is a certain production volatility as shown for the USA in Fig. 23. The probable reason being that vanadium can be substituted by other steel alloy metals. Manganese, molybdenum, niobium, titanium, and tungsten are to some degree interchangeable with vanadium (Polyak 2018). For example, a German steel plant reported that a certain quality of steel used for high-quality line pipes needed the microalloy elements niobium and vanadium. By adapting and changing the rolling mill procedure, $0.02 \%$ of titanium could substitute for $0.04 \%$ vanadium, leading to a significant cost saving (Wagner and Wellmer 2009). Such substitution effects can be implemented rather quickly following the relative price movements of alloy metals (Wellmer et al. 2018, Fig. 3. 13).

(b) Again, a hype element and speculation on the increased use of VRBs for large-scale storage of electricity as a

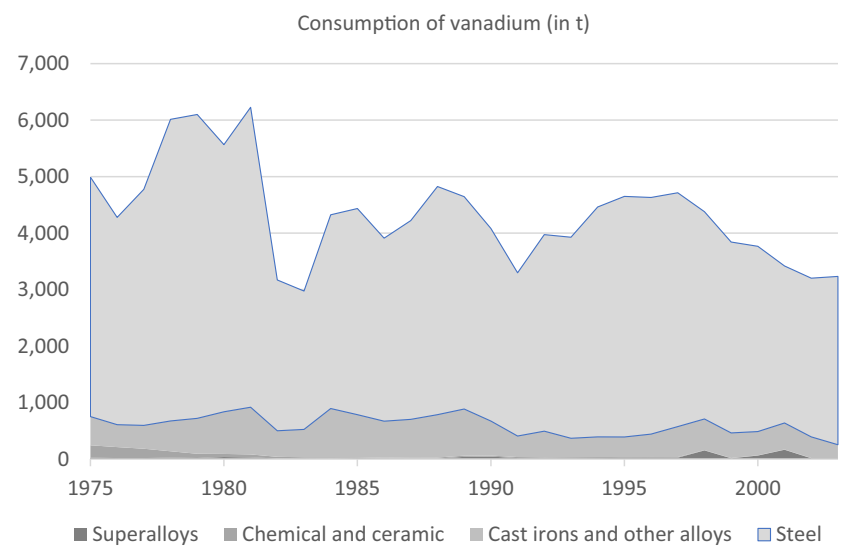

Fig. 23 Major end uses of vanadium in the USA from 1970 to 2011 (Kelley et al. 2017) 
future important technology for storing electricity and stabilizing supply from the only irregularly producing wind and solar power plants.

\section{The impact of producer associations on volatility-copper and aluminum}

Metal mining companies tried with international price agreements to fend off price fluctuations and price downturns as early as at the end of the nineteenth century. Efforts were made to influence prices for copper, zinc, lead, tin, aluminum, and nickel (Gocht et al. 1988). Initially pursued by private mining companies, after World War II, price agreements were increasingly sought for by governments of mineral-exporting countries. International cooperation agreements were signed to influence prices or at least to jointly promote the mineral export industry. Such associations were formed for copper, bauxite, iron ore, and tungsten.

The best known and partially successful were the ones for copper $(\mathrm{CIPEC}=$ Conseil intergouvernemental des pays exportateurs de cuivre) founded in 1967 and bauxite (IBA = International Bauxite Association) founded in 1974. Comparable with the OPEC (Organization of the Oil Exporting Countries) which could increase its oil revenues by $700 \%$ between 1970 and end of 1973, the IBA members managed to increase their bauxite earnings by similar percentages between 1974 and 1975 (Bergsten 1976). Such organizations work well in a seller's market, but eventually fail in a buyer's market. Non-members of the producers' associations will not cut production to stabilize prices and substitution processes take effect as will be described in "The tin crises - market interference and volatility" section on tin. With its member countries Chile, Peru, Democratic Republic of Congo, Zambia, Australia, Indonesia, Papua New Guinea, and Yugoslavia, CIPEC controlled about $30 \%$ of world copper refinery production; the share of primary production was even higher. However, Australia was not willing to agree to any market interventions as well in the copper market as in the bauxite market, too.

This was insufficient to stabilize market prices, and CIPEC was terminated in 1988. Concerning industry action alone, Herfindahl (1959) analyzed copper costs and prices and concluded that after World War I in the cases of common actionthe Copper Exporters Inc. (formed in 1926) and the so-called international cartel (formed in 1935) - the effect on price seems to have been distinctly limited. A good example for a price development under the influence of a cartel is the recent development of the oil price. OPEC was quite successful in stabilizing the price around US $\$ 100 / \mathrm{bbl}$ between 2010 and 2014. Subsequently, the price collapsed to about half of this level due to substitution effects prompted by shale oil from North America which had undermined the artificially sustained price level. As to volatility, the conclusion is that such cartels can manage to reduce volatility for a limited period of time and then tend to fail and turn into an agent of the market turbulences they were supposed to avoid.

\section{The impossibility of a minor metal market forecast}

\section{Technology uncertainties and substitution options in energy technologies}

As briefly mentioned in "Technological change" section, future demand on the metal markets will largely be controlled by an increasing pace of urbanization and the increasing number of consumers, especially in the growing middle class in India and China. This, combined with an increasing pace of technological development and market penetration, will be a volatility driver, especially on the minor metal market.

In this big picture, the transition of industrialized countries to a "low-carbon economy" is expected to play a considerable role in future metal markets (Drexhage et al. 2017). The major bearing seems clear - more energy efficiency, more renewable energies such as wind or solar power, electricity-driven mobility, and better energy storage facilities. While for wind power the technological route seems clearly pointing to ever larger offshore windmills, using permanent magnets based on REE such as neodymium/praesodymium and dysprosium, the technological path for road transport is far less clear (see, e.g., WI 2014). Today, the prevailing scenario seems to be batterydriven cars powered by renewably produced electricity. However, fuel cell-driven vehicles are a possible scenario, especially for heavy-duty trucks or ships. According to Robinius et al. (2018), infrastructure required for a hydrogen system is less costly than for battery-driven cars as soon as market penetration reaches 20 million units (Fig. 24).

The technological path will define the demand for minerals and create price volatility of minerals, many of which are produced predominantly in developing nations. The consequences for raw materials will be illustrated with a few examples. In Table 2, the raw materials are listed with a few key figures on the supply provided by developing nations.

- Battery electric vehicles (BEVs) vs. fuel cell electric vehicles (FCEVs). The standard battery so far is the lithiumion battery. It contains a typical material mix for the cathode of $11 \%$ lithium, $14 \%$ cobalt, $73 \%$ nickel, and $2 \%$ aluminum; the anode is made of graphite (Shankleman et al. 2017). For fuel cells for the hydrogen technology, the critical materials are the catalysts requiring the PGM metals platinum and palladium.

- With the transition to electric mobility, platinum and palladium, however, would lose their biggest application 
Fig. 24 Comparison of the cumulative investment of supply structures (Robinius et al. 2018) (with permission of HelmholtzResearch Center Jülich) (BEV battery electric vehicle, FCEV fuel cell electric vehicle)

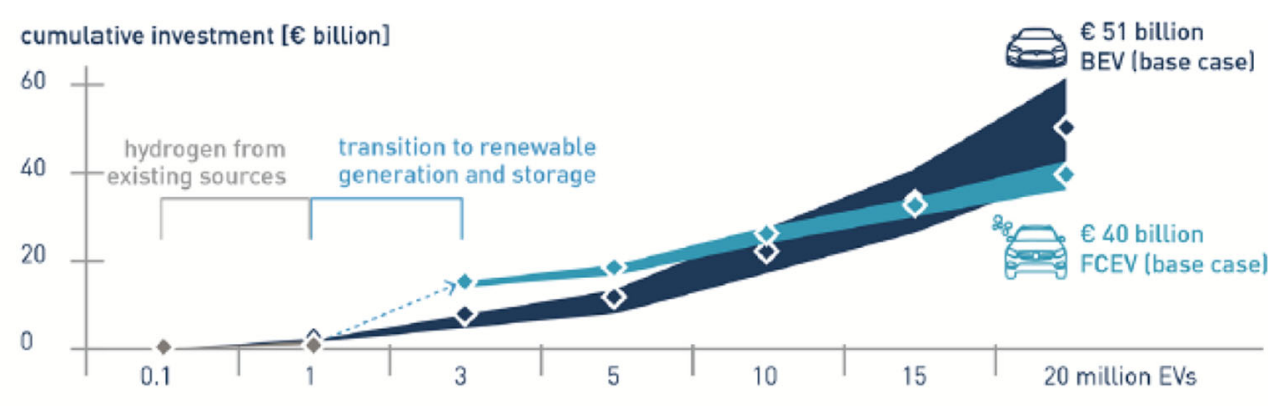

Figure 0-2: Comparison of the cumulative investment of supply infrastructures. sector, auto catalyst. In 2018, the share for platinum was $41.0 \%$, for palladium $83.4 \%$ (Johnson Matthey 2018).

- It seems that the power density of the lithium-ion batteries is approaching a limit with $250 \mathrm{~W} / \mathrm{kg}$. With other materials like magnesium, researchers hope to reach a loading capacity of $400 \mathrm{~W} / \mathrm{kg}$. Such batteries would also not need cobalt (Zhao-Karger et al. 2018).

- Such route would require boron as electrolyte bringing a new spectrum of supplier countries into the game of BEV (Table 2).

Table 2 Selection of minerals with a probable role in low carbon technologies (2016 data)

\begin{tabular}{|c|c|c|c|c|c|}
\hline \multirow[t]{2}{*}{ Raw material } & \multirow[t]{2}{*}{ HHI } & \multirow[t]{2}{*}{ WCR } & \multirow{2}{*}{$\begin{array}{l}\text { Main supplying countries } \\
(>5 \%) \text { without Australia, Canada, } \\
\text { Russia, and the USA }\end{array}$} & \multicolumn{2}{|c|}{ Considered critical minerals } \\
\hline & & & & EU* & USGS** \\
\hline Antimony & 5.051 & -0.39 & $\begin{array}{l}\text { China (67.6) } \\
\text { Tajikistan (16.9) }\end{array}$ & $\mathrm{x}$ & $\mathrm{x}$ \\
\hline Boron & 5.019 & 0.04 & $\begin{array}{l}\text { Turkey }(42.5) \\
\text { Chile }(13.0) \\
\text { Argentina }(7.0)\end{array}$ & $\mathrm{x}$ & \\
\hline Cobalt & 3.651 & -0.81 & $\begin{array}{l}\operatorname{DRC}(54.7) \\
\text { China }(8.3)\end{array}$ & $\mathrm{x}$ & $\mathrm{x}$ \\
\hline Graphite & 5.105 & -0.40 & $\begin{array}{l}\text { China }(69.3) \\
\text { India }(10.9) \\
\text { Brazil }(6.4)\end{array}$ & $\mathrm{x}$ & $\mathrm{x}$ \\
\hline Lithium & 3.006 & 0.99 & $\begin{array}{l}\text { Chile (39.8) } \\
\text { Argentina (15.6) } \\
\text { China (9.6) }\end{array}$ & & $\mathrm{x}$ \\
\hline Magnesium/magnesium compounds & 7.438 & -0.31 & $\begin{array}{l}\text { China }(64.7) \\
\text { Turkey }(12.5)\end{array}$ & $\mathrm{x}$ & \\
\hline Manganese & 1.695 & 0.05 & $\begin{array}{l}\text { South Africa (30.8) } \\
\text { China (14.0) } \\
\text { Gabon (10.8) } \\
\text { Brazil (7.4) } \\
\text { India (5.2) }\end{array}$ & & $\mathrm{x}$ \\
\hline Nickel & 1.036 & 0.16 & $\begin{array}{l}\text { Philippines (17.5) } \\
\text { New Caledonia (10.5) } \\
\text { Indonesia (8.7) }\end{array}$ & & \\
\hline Palladium & 3.151 & -0.04 & $\begin{array}{l}\text { South Africa (36.2) } \\
\text { Zimbabwe (5.8) }\end{array}$ & $\mathrm{x}$ & $\mathrm{x}$ \\
\hline Platinum & 4.460 & 0.07 & $\begin{array}{l}\text { South Africa (71.8) } \\
\text { Zimbabwe (8.1) }\end{array}$ & $\mathrm{x}$ & $\mathrm{x}$ \\
\hline Titanium & 1.384 & 0.60 & $\begin{array}{l}\text { South Africa }(17.5) \\
\text { China (17.4) } \\
\text { Mozambique }(7.3)\end{array}$ & & $\mathrm{x}$ \\
\hline Vanadium & 3.847 & -0.31 & $\begin{array}{l}\text { China }(52.5) \\
\text { South Africa (18.5) } \\
\text { Brazil }(9.3)\end{array}$ & $\mathrm{x}$ & $\mathrm{x}$ \\
\hline
\end{tabular}

Source WDB 2018. Source for HHI and WCR DERA Rohstoffliste 2016

*European Union Critical List (EC 2017a, EC 2017b, )

**USGS list of raw materials important to US economy (Schulz et al. 2017) 
- Another route being researched to replace cobalt and nickel as cathode material in lithium-ion batteries with manganese (Urquart 2018; Lee et al. 2018).

- Manganese is also seen as substitution (or at least a partial substitution) for PGM in catalysts for fuel cells and hydrogen production (Li et al. 2018).

Solar power and wind mills generate energy only intermittently. Various technologies have been developed to offset this disadvantage. One possible route is using redox flow batteries for electricity storage on a large scale, which would require large amounts of vanadium.

\section{Other uncertainties and possible substitution processes}

Eighty-four percent of antimony is used as flame retardant, in many industrial applications (Schwarz-Schampera 2014a). For antimony, it can be observed that the reserves/ consumption (R/C-) ratio has been decreasing for years (Wellmer et al. 2018, p. 180, Fig. 2a). Since reserves are dynamic figures due to continuous exploration, technology development, and changing prices, the ratio does not mean lifetime (Wellmer 2008). However, this ratio can be taken as an early warning indicator (Scholz and Wellmer 2013). At present, the antimony R/C- ratio stands at 10 (Klochko 2018) which is the lead time for new production and one of the lowest for any commodity of significance. Borate could replace antimony as flame retardant material (Firebreak 2019). Both the EC and the USGS consider antimony a critical material (Table 2), mainly because of its high production concentration in China. The industry is looking for a substitute. The early warning signs of a decreasing $\mathrm{R} / \mathrm{C}$ - ratio could be another motivation for industry to look for alternatives. In consequence, the supply situation could change totally. Two countries are by far the largest producers of borate-Turkey (more than 40\%) and the USA (WMD 2018).

The Turkish government considers borate a strategic resource. In addition, it should be mentioned that the use of permanent magnets (iron-boron-neodymium magnets) is currently increasing for renewable energy technologies, especially offshore windmills - so a possibly growing market for the raw material of borate, too, besides taking over the role of antimony.

Another element facing possibly major changes in its use is titanium. Within the EU, titanium dioxide is under scrutiny because of possibly carcinogenic health effects to humans (VCI 2016). On the other hand - although much smaller-a market could develop for perowskite, a calcium titanium trioxide for application in high-performance solar cells (Imran et al. 2018).
"Technological change" section discussed strontium, germanium, and gallium to show how volatility is triggered by technological change. These examples give a foretaste of what should be expected in the context of future energy technologies. Technological breakthroughs will be unexpected "black swans." There is no way to know when they appear, but there is certainty that they will (Taleb 2007). This also means that other technologies will become obsolete as shown with the example of the classical ray tube TV after the introduction of the LCD screens in "Technological change" section. Schumpeter (1912) called this process "creative destruction."

It is the impossibility to forecast future demand for minor metals that provides the precondition for innovation. This applies not only to metal markets. The philosopher K. Popper (Popper 1988) claimed that for radically new innovations to occur at all, the future must be unknowable, for otherwise an innovation would, in principle, be already known and would occur in the present and not in the future.

\section{The producing countries' perspective-two case studies}

To illustrate volatility drivers, their interaction in the metal markets and exposure of resource-dependent countries to its effects, we shall describe two cases in detail: the Chilean saltpeter mining industry and the international efforts to stabilize the tin price. The saltpeter case is a classic example of volatility created by changes in demand patterns due to technological breakthrough in an industrial, raw material importing country, and the inability of producers to adjust. It is also an example of the drastic effect on the well-being of developing nations dependent on the export of a single commodity. The second case, tin, a commodity produced predominantly in developing nations $(98 \%)$, is an example for volatility created by political measures to stabilize prices by the various International Tin Agreements.

\section{Rise and fall of the Chilean saltpeter-based economy 1880-1930}

Justus von Liebig recognized the importance of fertilizers for agricultural productivity. After his publication on agricultural chemistry (von Liebig 1840), fertilizer demand grew, and productivity took a leap forward. As an example, between 1873 and 1913, the agricultural production in Germany increased by $90 \%$ (Fesser 2000). Still, at the end of the nineteenth century, the UK and Germany were struggling to feed their increasingly urbanized population. Both countries had put virtually all their arable land into relatively intensive production and were the largest importers of nitrates and leading producers of ammonia from coking. Yet both countries were large wheat importers (Smil 2001). 
Peru had started to supply the world with fertilizers since the mid-1800, first as guano - excrement of seabirds and bats, an effective fertilizer due to its high content of nitrogen, phosphate, and potassium. During what in Peru is considered "The Guano Republic" (1845 to 1866), the guano industry was the main source of state revenue.

Guano reserves declined in the late 1860s and was increasingly replaced by saltpeter (Greenhill and Miller 1973) - sodium nitrate - found in salt pans that extended across the prePacific War borders of Chile, Bolivia, and Peru.

Inspired by the saltpeter business, Chile occupied Antofagasta and later declared war on Peru. The War of the Pacific resulted in the annexation of the territory, making Chile the sole owner of the world's only known deposits of nitrate of sodium (Crozier 1997).

Saltpeter production on Chilean soil increased rapidly (Fig. 25). What followed was a time of unprecedented economic wealth in Chile. Prices fluctuated between 350 and 500 USD per ton (in 1995 USD), and in 1913, annual production reached a first peak of 2.7 million t. Saltpeter became known as the "white gold" and provided almost $60 \%$ of state income (Wisniak and Garcés 2001).

But nitrogen is not only an essential ingredient for fertilizers, it also is a main component for explosives; it therefore was of great strategic importance in times of a looming war in Europe. In both strategic areas, industrialized countries were dependent on the supply of a virtual monopoly holder: Chile.

Germany accounted for about one third of the total Chilean exports in 1912 (Fig. 26, Wisniak and Garcés 2001). There was a strong incentive to become independent from Chilean nitrate supply and an understanding that the solution would be found in the unlimited availability of nitrogen in the air.

Germany had pushed technological development to generate synthetic ammonia. Fritz Haber laid the foundations for it, and the industrialist Carl Bosch subsequently developed it on an industrial scale. In 1913, BASF put a plant into operation with an initial capacity of 30 t per day. As early as 1914, production had reached industrial scale (Couyoumdjian

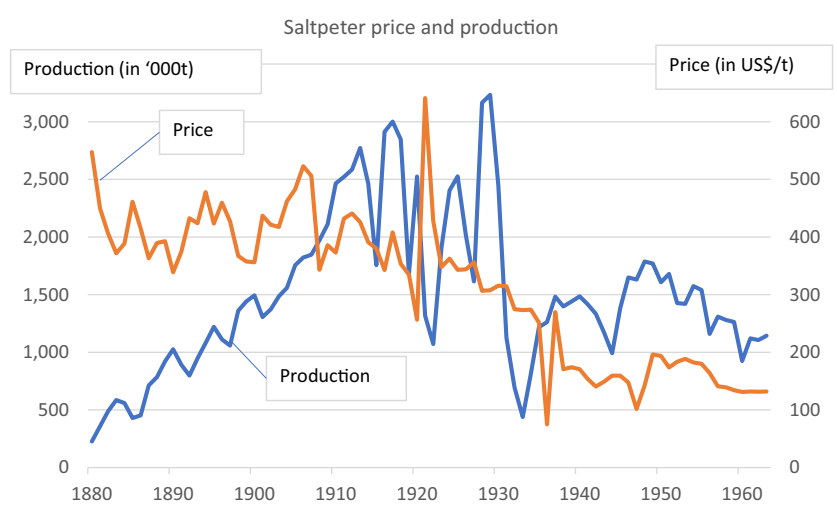

Fig. 25 Saltpeter price (USD/t, displayed on the right axis) and Chilean production (in t, on the left axis). Data: from Braun-Llona et al. (1998)

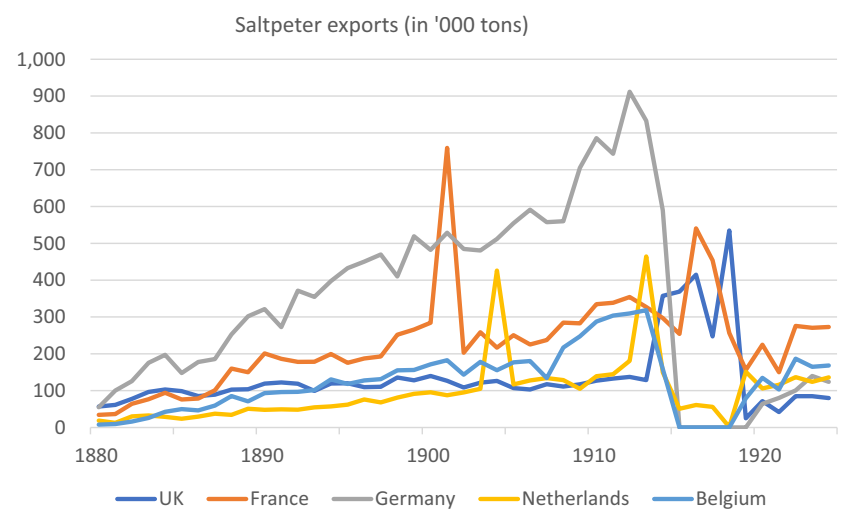

Fig. 26 Chilean nitrate export per destination, in million tons, data from Ministerio de Hacienda, Chile 1925

1975). The downfall of saltpeter mining now was a mere question of time.

With the beginning of hostilities in Europe, Britain imposed a saltpeter embargo on Germany in 1914 and the Chilean saltpeter production suffered a first serious downturn (Figs. 25 and 26). Subsequently, prices declined, imploded during the big depression, and never recovered again (Fig. 25). Chile, having been a buzzing economy for decades, had amassed substantial foreign debt, now hard to service, and defaulted in 1931 (Ministerio de Economía, Fomento y Turismo de Chile 2015).

But the Haber-Bosch process also had a much longer term impact. The nourishment of industrial societies with an increasing share of population living in cities would not have been possible only with applying organic manure and crop rotation with lupines. Synthetic nitrogen fertilizer dramatically increased global agricultural productivity in most regions of the world and boosted world population (Erisman et al. 2008, Fig. 27).

Figure 25 shows nearly a classic "Hubbert" curve for production developing over years, with a rise in production, a plateau phase, and then a decline, even more than Fig. 10 for strontium with its rapidly occurring peak. However, as in all other cases shown in this paper, this is a demand-driven peak and decline of production, as opposed to the model proposed by Hubbert, which assumes production peaks to be driven by supply shortage. When production of Chilean nitrate started to decrease, there were no supply problems arising from the exhaustion of the available natural sources for this resource (McConnell 1935).

\section{The tin crises-market interference and volatility}

The tin crisis in the 1980s provides an example of volatility where interaction of technological change and price manipulation through a producer cartel ended in price collapse and the tin market breakdown. 
Fig. 27 Trends of human population and nitrogen use throughout the twentieth century (Erisman et al. 2008). The actual world population is represented by the solid line. In contrast to this, the graph shows the world population that could have been sustained without reactive nitrogen from the Haber-Bosch process (long dashed line), both on the left axis. The short-dashed line provides an estimate of the percentage of the global population sustained by nitrogen generated with the Haber-Bosch process (right axis)

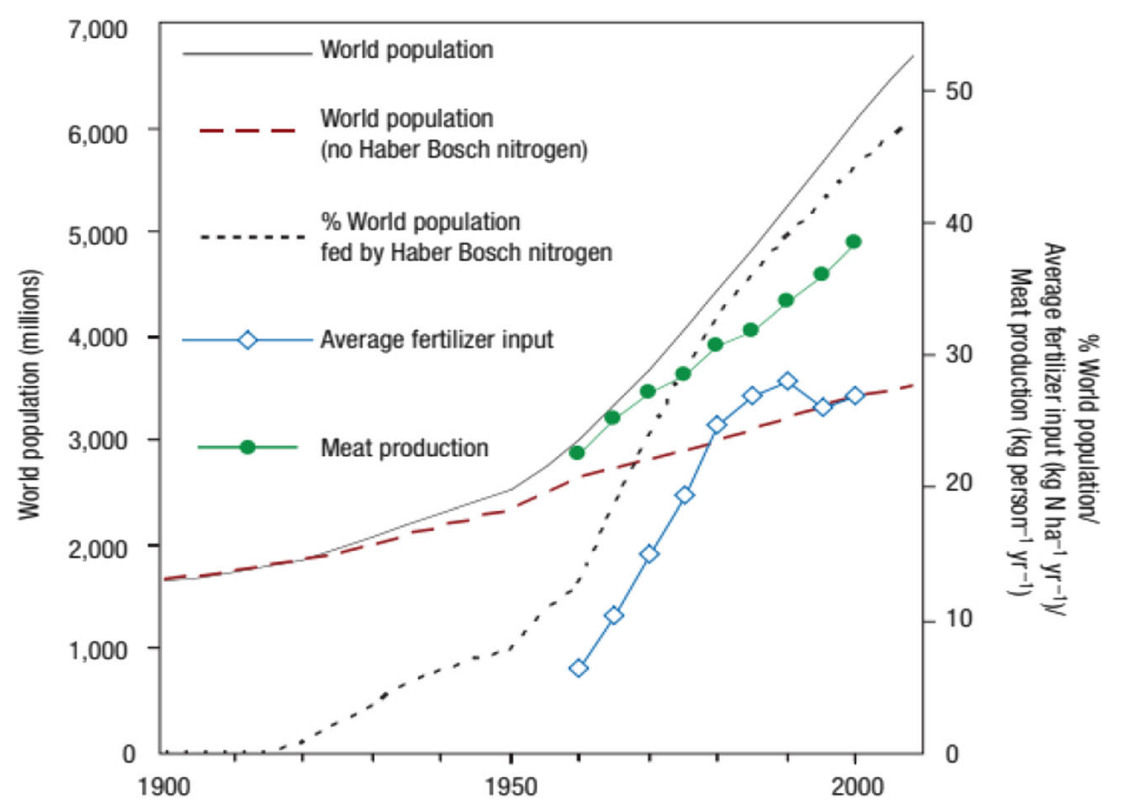

Tin mining is concentrated in developing countries. In $1977,90 \%$ of mine output was produced in eight countries, the largest producers being Malaysia $(65,000 \mathrm{t})$, Bolivia $(31,000 \mathrm{t})$, USSR $(31,000 \mathrm{t})$, and Thailand $(24,000 \mathrm{t})$ (Witzig 1981). The high volatility was especially destabilizing for marginal and high-cost producers, such as the lode mine industry in Bolivia, as opposed to low-cost tin placer mining in Southeast Asia. Thus, highly exposed to the tin price slump during the great depression, Bolivia was the first country to file for default on its foreign debt in 1931 (Morales and Sachs 1987).

During the first half of the twentieth century, tin prices and production fluctuated strongly (Fig. 28), with recurring highproduction deficits and surpluses (a $45 \%$ of consumption surplus in 1921 and a deficit of 23\% in 1959). A high volatility and little elasticity (Witzig 1981) were attributable to the fact that tin was a minor component of finished products with little options for replacement.

Inelasticity was exacerbated by the structure of the mining industry. Into the $1980 \mathrm{~s}$, a substantial part of production was government-owned. Mines would continue operating during a price slump even under heavy losses for reasons of domestic politics, thus subsidizing output and obstructing effective price regulation.

Like for other base metals, measures were taken in the first half of the twentieth century to reach agreements at the international level to influence and stabilize prices. Tin is the raw material with the most international commodity agreements aiming to stabilize prices, namely 10 since the beginning of the last century (Jütte-Rauhut 1989).

Generally, prior to World War II, large companies tended to organize themselves. After 1945, agreements were reached at
Fig. 28 Tin prices (in 1998 US\$) and world production 1900 to 2015 (data: USGS Historical Statistics 2019)

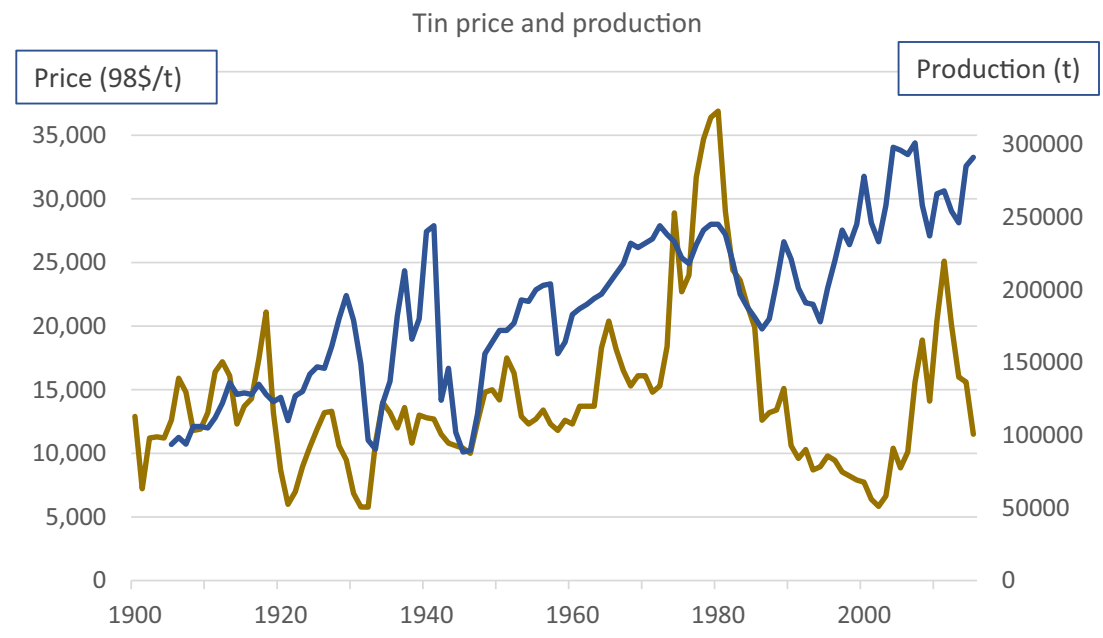


an intergovernmental level. For tin, there was the Bandoeng Pool from 1921 to 1925, the Malayan Tin Trust in 1928, the Tin Producers Association in 1929, and the International Tin Control Scheme from 1931 to 1946, with tin quotas and tin buffer stocks (Gocht et al. 1988). In 1947, an International Tin Study Group was set up in the Netherlands to prepare the draft for an international tin agreement which was negotiated at a conference in 1953.

Finally, the International Tin Agreement (ITA) was established in 1956 to stabilize the world tin market and counteract the impacts of commodity market cyclicity such as unemployment in producing countries during price slumps and secure continuous supply in consuming countries during economic recovery. It was the first intergovernmental commodity agreement on a metal market (Gocht et al. 1988).

Consuming and producing countries were part of the agreement. The International Tin Council (ITC), the executive arm of the ITA, was given authority to maintain the price within a range that was acceptable to all the members. The ITC used buffer stocks and import quotas to control the price and world supply of tin (Chandrasekhar 1989).

The ITA was supposed to be the model for the "new economic order." In 1974, the Sixth Special Session of the UN General Assembly in New York had adopted the "Declaration on the Establishment of a New International Economic Order" to improve terms of trade for developing countries. The agreement promoted international commodity agreements to regulate prices and exports, guarantee sales, finance surplus production, and compensate for loss of export earnings of developing nations. The UNCTAD V conference in Manila 1979 established the "Integrated Program for Commodities" and the "Agreement Establishing the Common Fund for Commodities" (Gocht et al. 1988).

In 1975, the largest use of tin was in tin-plated steel, accounting for more than $40 \%$ of total consumption in the USA. Most of it was used to make food and beverage containers (tin cans). The cost of tin, however, amounted to less than $2 \%$ of the cost of tin plate. The second largest use of tin is in solder, which accounts for about $25 \%$ of consumption.

With the beginning of the fifth ITA in 1975, producing countries - especially those with the higher cost mines, such as Bolivia-advocated for a higher price band. Relatively high prices and the expectation that prices were not going to fall below the artificially established floor, led to a declining intensity of use of tin during the 1970s and into the 1980s. Tinproducing countries maintained their income at the cost of pricing tin out of many of its markets.

For example, tin was replaced by sodium as the carrier of fluoride in toothpaste (Crowson 2008). However, the decisive change occurred in tin's major market, canning, where tin was replaced by plastics and aluminum while, at the same time, tin recycling increased. In the USA, the largest consumer market, tin consumption for canning dropped by more than $60 \%$, from
24,600 $\mathrm{t}$ in 1975 to $9380 \mathrm{t}$ in 1985 (data: USGS Historical Statistics 2019). Figure 29 shows the declining usage of tin for can and container production as opposed to the rising importance of aluminum.

Markets once lost are hard to recover. Figure 30 shows the long-term impact of price manipulation on tin production. Price increases encouraged consumers to use it more thriftily or to substitute it with the consequence of zero or even negative consumption growth, whereas the other base metals with no market interventions enjoyed significant demand growth.

The tin market moved from being inelastic into a condition in which tin competes directly with other products and consumption reacts to price signals. Despite its efforts to manage tin prices and supply, the ITC lost control of the market. Tin supply increased as new producers like Brazil entered the market and rejected membership in the ITA (McFadden 1986).

Many of the members abandoned the mechanism of the council and independently intervened in the tin market to pursue their own perceived best interests. ITC further imposed export controls, but this was to little avail, as global production of tin had exceeded consumption since 1978 (Mallory 1990). The appreciation of the US dollar gave the final blow. ITA price targets were expressed in Malaysian ringgits, which were linked to the dollar while the LME price was expressed in pound sterling, making it impossible to defend the ITA floor price. The price of tin never increased enough to allow the manager to sell off the buffer stock holdings.

On October 24, 1985, the buffer stock manager of the ITC, Pieter de Koning, announced to the LME that he had insufficient funds to honor his contracts. In defending the agreed floor price, it later turned out, the ITC, acting through de Koning, had not only depleted the cash reserves of the buffer stock but also financed future purchases through broker and bank loans amounting to $£ 900$ million. The ITC tin stockpile, including physical metal and contracts for future delivery, had grown to over 100,000 t, equivalent to over 6-month world consumption. The LME, the world's largest tin market, suspended trading in tin immediately after de Koning's announcement (McFadden 1986). Tin trading was resumed only in 1989 (Kestenbaum 1991).

In Bolivia, the collapse of the tin price, combined with a slump in oil prices, both adding up to $77 \%$ of Bolivian exports in 1985 , drove the country into virtually complete default (Sachs 1987). The collapse of the ITC was also the end of the UN efforts to stabilize commodity prices via raw material agreements within the "New International Economic Order."

In hindsight, the ITC not only was unable to stabilize prices and even out production cycles, it produced a massive price peak, unsustained by demand and a subsequent slump with a profound economic impact in producing countries. This example is a reminder that price volatility acts as a necessary signal to both producers and consumers and that attempts to 
Fig. 29 Tin and aluminum usage in cans and containers in tons. Aluminum tonnage is displayed on the right axis, tin on the left. Growth of aluminum is almost 40 times the tin market share. (data: USGS Historical Statistics 2019)
Tin and aluminum usage in cans and containers

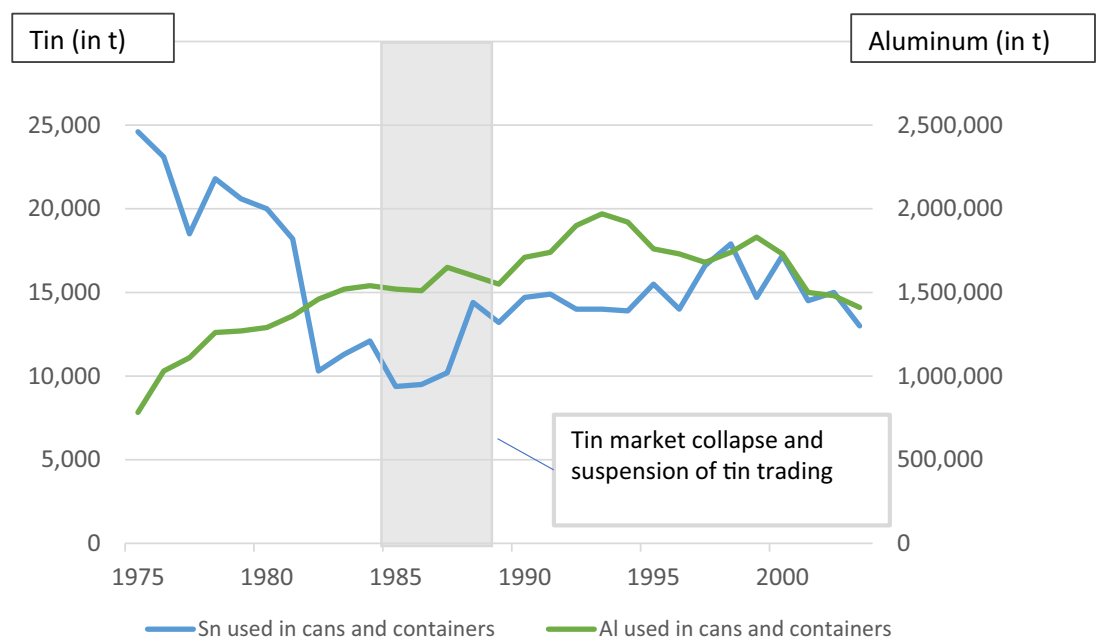

reduce volatility are likely to lead to more persistent and larger market imbalances.

\section{Implications for producing countries-the road ahead}

\section{Introduction}

Industrialized countries tend to exhibit stable growth rates over long periods of time, whereas growth rates in poorer countries are prone to sharp fluctuations (Lucas 1988). The negative correlation of output fluctuation and development was documented in detail by Ramey and Ramey (1995). Raddatz (2008) shows for Latin American countries that fluctuations in growth rate are largely controlled by external shocks, namely shocks to the terms of trade. ${ }^{6}$ Many times, erratic fiscal and monetary policy exacerbate the impact (Loayza and Raddatz 2006).

The negative correlation of GNP fluctuation and development is closely related to the poor economic diversification in developing countries and the disproportionate importance of the commodity sector, which typically has the highest volatility (Koren and Tenreyro 2007). In countries with little diversification and a substantial dependence on mineral production, the terms of trade are therefore to a large extent controlled by commodity prices on the global markets (Kohlscheen et al. 2017; Jacks et al. 2011). In these countries, high price volatility on the mineral markets not only places a burden on shortterm macrofiscal stability but hampers growth and development at large (Radetzki and Warell 2017, p. 98/99). This

\footnotetext{
$\overline{6}$ The terms of trade represent the ratio between a country's export prices and its import prices.
}

section attempts to quantify the economic exposure of producing countries caused by price volatilities on the mineral market and suggests possible policy responses.

\section{Exposure of producing countries}

Table 2 provides an overview of metals with a demand subject to technological development and the current supplying countries (with a share $>5 \%$ ). In some cases, supply is highly concentrated in very few countries. Depending on their respective weight in the national economy of a particular country, their price and price fluctuations can have a substantial impact on economic development of the host country.

The two columns on the right side identify those minerals that have been classified as "strategic" or "critical" for their own economies by EU and USGS, based on country concentration, "country risk," and the importance of that particular mineral for their own (demand side) economies. However, as

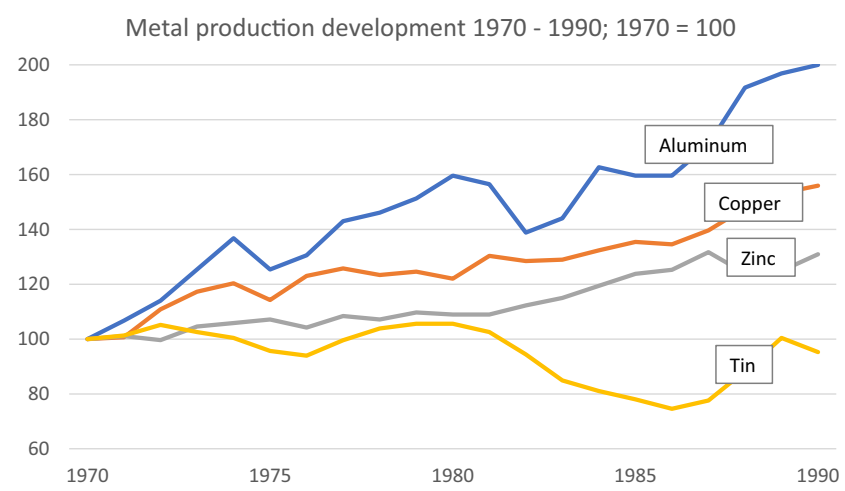

Fig. 30 Tin production as compared with production of aluminum, copper, and zinc 1970 to 1990 , normalized to 1970 production $=100$. Tin was priced out of decisive markets during the 1970s and 1980s and was unable to recover 
discussed in "Supply-side-driven volatility" section, market data shows no evidence that country concentration and country risk systematically affect market balance and supply risk. Data discussed in "Country risk" and "The effect of hypes" sections suggest that it rather is the classification itself that would contribute to volatility and market imbalance.

Countries' economies will be exposed to commodity price volatility to the extent of their dependence on a specific commodity. An economy's dependence on minerals can have many aspects - the mineral industry may be a major customer of a local supply industry, be a major employer as seen in the Saltpeter chapter, or provide the commodities needed in the country's industry as is the case for a substantial part of Chinese mineral production.

For the purpose of this paper however, we look at the share of mineral commodities in total exports. Price fluctuations on the mineral markets will directly affect a country's balance of payments. In a resource-dependent country, a commodity's price collapse will likely produce a BoP shock. As shown in the examples provided in "The producing countries' perspective - two case stories" section, this can heavily affect a country's capacity to serve its foreign debt and its access to international financial markets and ultimately lead to sovereign default. Resource-dependent countries have a special inclination to run into debt crises when large discoveries fuel expectations in the population and spark government spending even before revenue flows. In a context of narrow budgets and limited capacity to serve their foreign debt, a BoP shock can have severe consequences.

Dependence of a country's economy on a specific mineral commodity is therefore expressed as the share of that specific commodity's value in a country's total exports (year 2016, data source: UN Comtrade 2019). The higher the share of a specific commodity's production value in a country's exports, the higher the vulnerability of the producing country's economy to the effects of that commodity's price volatility. Exposure is therefore presented as a product of dependence (production value as percentage of total exports) and actual volatility of the commodity.

Figure 31 visualizes country exposure for a selected group of minerals. Price volatility is expressed on the $y$-axis (average standard deviation between 1975 and 2012, calculated using a moving standard deviation with a 7-year window). The graph displays exposure of a specific country to price volatilities of a specific commodity. The farther in the upper right corner, the higher the exposure of the country's economy. High exposure is evident for DRC to cobalt price fluctuations, Rwanda to $\mathrm{Nb}$ / Ta markets, Suriname and Burkina Faso and Mali to the gold market, Zambia to copper, etc. High exposure to price volatility is also evident in Chile to copper (a 15 million people economy providing almost $30 \%$ of the world copper production), but as opposed to most other countries, Chile has powerful macroeconomic safeguards in place to isolate its economy from price fluctuations on the international markets (Korinek 2013).

It is to be noted that total exposure of a country's economy to price volatilities will be determined by the accumulated dependence and price volatilities of its commodities. In many cases, it will be the combined effect of price volatilities that put a country in distress, as shown in "The tin crises-market interference and volatility" section for Bolivia that had to file for default on foreign debt as a consequence of a combined price slump of its main export products, tin, and oil.

This graph is based on average price volatilities between 1975 and 2012; it does however provide limited information on what is to be expected in the future in terms of volatility, especially of minor metals. As discussed in the above sections, there is little benefit in forecasting demand and prices for most of the minor metals, mainly due to unknown technological paths and a complex interaction of other volatility drivers such as technological change, speculation, substitution, hypes, or mere risk perception. However, for some minerals, potential substitution scenarios can be identified, as discussed in "Technology uncertainties and substitution options in energy technologies" and "Other uncertainties and possible substitution processes" sections.

\section{Policy response}

During the industrial revolution in central Europe and the UK, technology developed around coal and steel production. Since then, the rules of the game have changed. Today, proximity to the mine is no competitive advantage for industrialization, not even for bulk minerals. Transportation costs have become an almost negligible factor. Australian alumina is refined in Mozambique and Chilean copper in Europe or China. Low transport costs have made the commodity market a global one as mentioned in "Introduction" section. Lower tariffs have added to globalization of value chains and brought to the fore other locational advantages such as energy costs or proximity to the downstream markets. The term "smelter at the market" has been coined to describe this advantage of smelters producing even semifinished products such as "tailored blanks" for the automotive industry close to the customer.

Today, wealth in mineral resources does not automatically trigger technological development, on the contrary. It is a potential source of state income, but it tends to hamper the development of a manufacturing industry and can complicate development as a whole ("Introduction" section).

High-value mineral exports are likely to either strengthen local currency or accelerate inflation or both. In both cases, real exchange rate appreciation weakens the competitiveness of the country's exports and, hence, causes its manufacturing industry and traditional export sector to shrink. This process adds to the resource dependence and places a heavy burden on the local economy - the Dutch disease also called the natural 


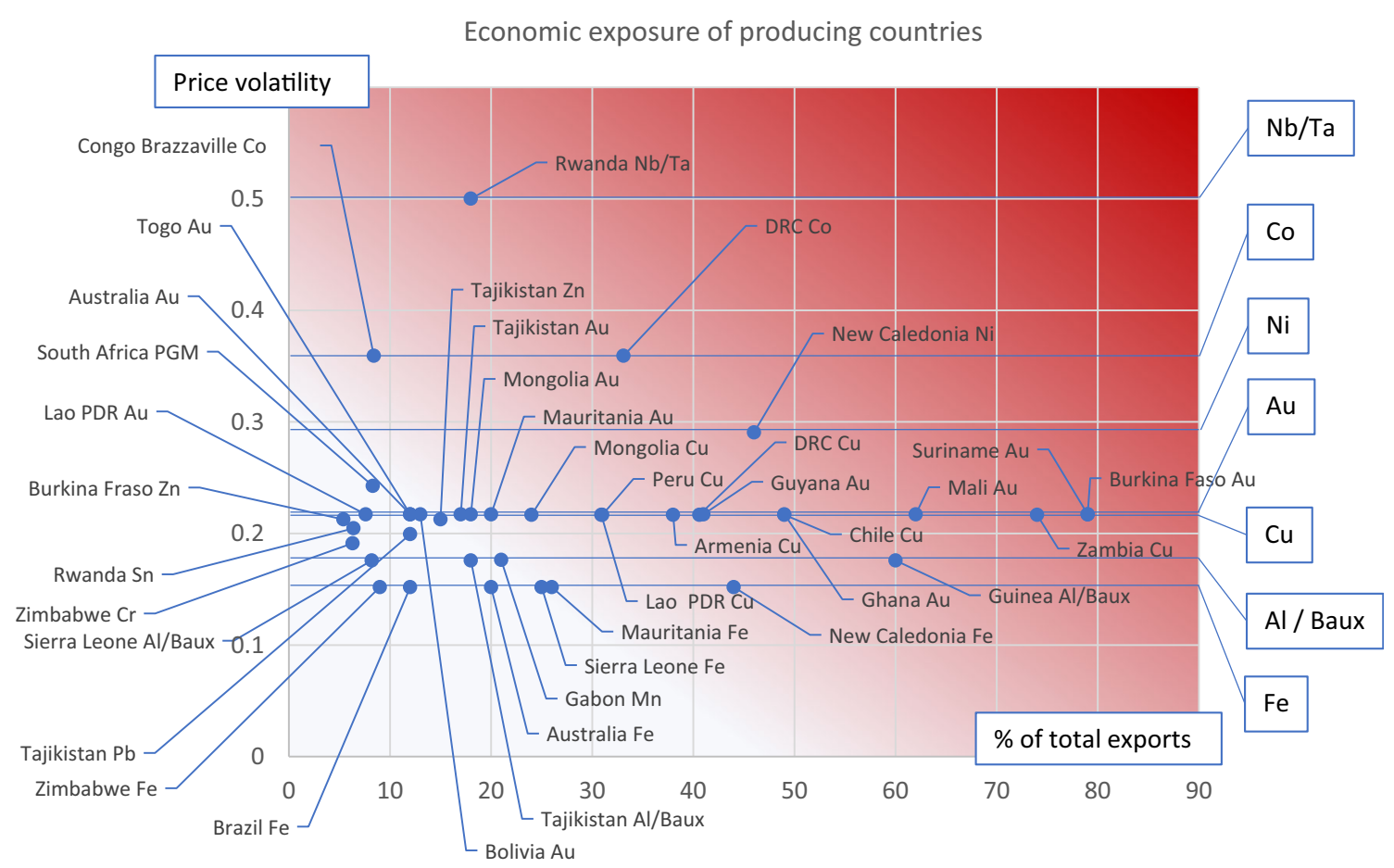

Fig. 31 Exposure of producing countries to price volatility of specific minerals. The colored area stands for high volatility and high economic dependence of the producing country, resulting in high exposure. Volatility ( $y$-axis) is calculated by the authors as the average of a moving standard deviation (1975-2012) with a 7-year window, based

resource curse (Frankel 2010). This tends to create a vicious circle in which resource dependence and exposure to price fluctuations on international commodity markets becomes a self-reinforcing process. Therefore, for most mineraldependent countries, the ultimate development goal is becoming less dependent from their commodity exports, reducing exposure to global market shifts and diversifying their economy. But diversifying an economy from mining into manufacturing is overly challenging.

Much has been written on the potential of establishing linkages between the mining sector and a manufacturing and service industry, and different countries have attempted different approaches. The World Bank assisted several West-African countries in their efforts to identify their opportunities for building a local mining supply industry and facilitating local procurement of goods and services based on competitive advantages (World Bank 2015). The reason why today manufacturing does not grow naturally around the mine sites is not only exchange rate related. Lack of skilled workforce and an increasing technological gap between mining operations and the local industry are major challenges that require coordinated action of industry and government to seize potentials.

Other approaches have been more prescriptive, as in Indonesia, where the government in 2014 introduced a ban on export of nickel concentrate and bauxite to enforce in-country processing, or in Bolivia, where lithium mining was made on USGS price data (USGS Historical Statistics 2019). Economic dependence ( $x$-axis) is represented by the production value of a specific mineral as share of total exports of the producing country (data: USGS Historical Statistics 2019 and UN Comtrade 2019)

conditional to establishing a fully integrated in-country value chain from mine production to battery manufacturing. The results have been modest so far. As a principle, prescriptive approaches that defy economic rational are not likely to succeed.

Even well-governed countries such as Chile, Australia, and Norway grapple with this burden derived from the high proportion of commodity revenues in their economy (a powerful indicator is the closure of Australia's last automobile factory in 2017). With great effort, the three countries have managed to build up a local industry around the extractive sector, using the sector for knowledge development and a high-tech service industry that has become competitive on the international market. Most resource-dependent countries have been less successful in this endeavor.

This paper shows that volatility of minor metals adds another layer of complication to it. Integrating minor metal mining into a national structural development will be more difficult in an uncertain future mineral market and the looming risk of stranded assets. Producing countries would benefit from considering the fundamental difference between major metal and minor metal markets and taking into consideration increasing uncertainties of minor metal demand when designing a national mineral policy.

National mineral policies built on major metals can count on a continuous and growing demand. Large assets of major 
metals such as copper, iron, aluminum, and zinc will allow for long-term planning that includes long-term albeit varying state income as well as efforts to weave the mining industry into a local economy via linkages and shared infrastructure. Minor metals on the other hand will require a different approach. Industrialization policies around minor metals such as building in-country value chains are at risk to fail due to high demand volatility that in many cases will relate to quickly shifting demand patterns.

The main benefits to be gained from minor metal production will probably not be related to local linkages and local beneficiation but rather constrained to fiscal returns. Then again, to benefit from fiscal returns, a country needs to have not only an efficient fiscal framework but also capable institutions in place to enforce its regulations. Another question to be considered is as to the most adequate and efficient tax arrangements for minor metals, i.e., if for instance royalties are an adequate levy for a product with highly volatile demand and price.

\section{Conclusions}

Metal markets are predominantly buyer's markets. Prices and their volatility are largely dictated by shifting demand patterns. No evidence has been found that country risk or country concentration of production has led to sustained market imbalance in the past or would do so in the future ("Supply-side-driven volatility" section). Specific supply-side shortages are the exception. The Shaba crisis and its effects on the Cobalt market shown in "War and civil crises as volatility driver-cobalt" section is a rare example of a shortage on the supply side. More importantly, it shows that the subsequent price peak was short-lived and that the reaction on the demand side, as in other cases, has a deeper impact on the market than the initial shortage itself. This observation is corroborated in the case studies in "The producing countries' perspective - two case studies" section.

It therefore seems likely that risk perception itself induces a process that emulates a market reaction to a real risk, as shown in "The effect of hypes" section. In light of a perceived supply risk, companies build stocks, diversify supply sources, engage in long-term supply contracts, integrate backwards into production, increase recycling, and delve into substitution. Substitution can have a major influence on price volatility, as shown in "The role of substitution" section in which perception itself triggers a reaction that produces volatility, seemingly confirming the previous risk assessment.

In "Technological change" section, we discussed the increasing intensity of demand peaks. This tendency will continue. Intensity of demand peaks will increase not only due to major technological shifts and an accelerating pace of technological innovations, but mostly related to a rapidly growing middle class in China and India. Within this larger picture, the transition to a low carbon economy will play a major role (Wellmer et al. 2018). Construction of a renewable energy unit, especially for electrical energy, will consume substantially more raw materials per energy unit produced than fossil energy plants (Vidal et al. 2013; Hertwich et al. 2014; Drexhage et al. 2017). Not only more copper, aluminum, and steel, but specifically, more minor metals will be needed to build energy-efficient wind and solar energy-generating facilities, batteries, hydrogen storage, and other systems related to the energy transition. This will most likely have a substantial, but at individual commodity level, a largely unpredictable impact on the minor metal market.

As opposed to minor metals, major metals have a large number of applications. Technological changes have an impact on major metal demand too, and substitution processes take place on the path to a low carbon future, but their impact on total demand for a major metal is less important. Except for lead, they will not be entirely replaced, but will most probably grow at differing paces. With the increase of electric mobility and an envisaged peak oil demand in the 2030s, a peak lead demand will most probably follow because $80 \%$ of the metal is used in starter batteries (Oxford Institute for Energy Studies 2018; McKinsey and Co 2019).

Yet, for minor metals with few and specific, mostly high-tech applications, demand is controlled by a complex interaction of all drivers discussed in this paper. Technological change plays a major role in it, but other factors such as speculation, government interference, substitution, and mere perception can be equally powerul. The complexity of this interaction makes it impossible to forecast which of them will play a dominant role and which will fall back into a niche state.

To be able to benefit from production of minor metals in an environment of permanent change, producing countries must consider the fundamental difference between major metal and minor metal markets in their national mineral policy.

Acknowledgments The authors thank Evelyn Dietsche, Paulo de Sa, Peter Buchholz, and two unknown reviewers for their review of the draft and helpful comments. Acknowledgments go to C. Hagelüken and H. Elsner for critically reviewing the sections on PGM and REE, respectively.

Open Access This article is distributed under the terms of the Creative Commons Attribution 4.0 International License (http:// creativecommons.org/licenses/by/4.0/), which permits unrestricted use, distribution, and reproduction in any medium, provided you give appropriate credit to the original author(s) and the source, provide a link to the Creative Commons license, and indicate if changes were made.

\section{References}

Ames Laboratory (2008) Alternatives to lead-based solders. https:/www. ameslab.gov/files/LeadFreeSolder_Foundation.pdf Accessed 9 March 2019 
Arnon DI, Stout PR (1939) The essentiality of certain elements in minute quantity for plants with special reference to copper. Plant Physiol 14(2):371-375

Bergsten CF (1976) A new OPEC in bauxite. Challenge 19(3):12-20

Berner G (2000) Grenzenlose Mobilität. Siemens Standpunkte 1:16-21

BGR data base (2018)

BGR, DIW, ite (1997): Bundesanstalt für Geowissenschaften und Rohstoffe; Deutsches Institut für Wirtschaftsforschung; Institut zur Erforschung Technologischer Entwicklungslinien. Ausfallrisiko bei 31 Rohstoffen; Bundesanstalt für Geowissenschaften und Rohstoffe, Hannover, Germany; Deutsches Institut für Wirtschaftsforschung, Berlin, Germany; Institut zur Erforschung Technologischer Entwicklungslinien, Hamburg, Germany

Bräuninger M, Leschus L, Rossen A (2013) Ursachen von Preispeaks, - einbrüchen und -trends bei mineralischen Rohstoffen. In: DERA Rohstoffinformationen Nr. 17, commissioned study by Hamburgische WeltWirtschaftsInstitut (HWWI) for the deutsche Rohstoffagentur at the Bundesanstalt für Geowissenschaften und Rohstoffe, Berlin

Braun-Llona J,Braun-Llona M, Briones I, Díaz-Bahamonde J, Lüders R, Wagner G (1998). Economía Chilena 1810-1995. Estadísticas Históricas, No 187, Documentos de Trabajo, Instituto de Economia. Pontificia Universidad Católica de Chile. https:// EconPapers.repec.org/RePEc:ioe:doctra:187 Accessed 3. April 2019

Buchholz P (2013) Entwicklung von Frühwarnindikatoren für die Rohstoffrisikoanalyse. In: BGR- Rohstoffkonferenz 2013, Hannover, 4. November 2013

Buchholz P, Wellmer FW, Bastian D, Liedtke M (2019) Real price benchmarks as a tool for acting anticyclically in the raw materials business -100 years of real price time series. Miner Econ (submitted)

Butcher T, Brown T (2014) Gallium. In: Gunn G (ed) Critical metals handbook, Chichester UK. Wiley, pp 150-176

Carlin JF (1985) Tin. Mineral facts and problems, US Bureau of Mines Bulletin 675:847-858

Chandrasekhar S (1989) Cartel in a can: the financial collapse of the International Tin Council. Northwestern J InternLaw Bus 10(2): 309-332. https://scholarlycommons.law.northwestern.edu/njilb/ vol10/iss $2 / 28$ Accessed 20 February 19

Couyoumdjian R (1975) El Mercado del Salitre durante la Primera Guerra Mundial y la Postguerra 1914-1921, Notas para su Estudio, Historia Vol. 12 (1974-1975):13-55, Publicación del Instituto de Historia, Universidad Católica, Santiago, Chile

Crowson P (2008) Mining unearthed. London, UK (Aspermont)

Crozier R (1997) El Salitre Hasta la Guerra del Pacifico: Una Revisión. Historia, 30:53-126. Instituto de Historia, Pontificia Universidad Católica, Santiago de Chile

Damm S (2018) Rohstoffrisikoanalyse Tantal. DERARohstoffinformationen 31, Deutsche Rohstoffagentur (DERA) in der Bundesanstalt für Geowissenschaften und Rohstoffe (BGR)

DERA (2017) DERA-Rohstoffliste 2016. Angebotskonzentration bei mineralischen Rohstoffen und Zwischenprodukten - potenzielle Preis- und Lieferrisiken, Hannover, https://www.deutscherohstoffagentur.de/DERA/DE/Downloads/rohstoffliste-2016. pdf?_blob=publicationFile. Accessed 10 April 2019

DERA (2018) Chart des Monats, November 2018-VanadiumPreisralley seit 2016

DERA (2019): Volatilitätsmonitor. https://wwwdeutsche-rohstoffagenturde/ DE/Themen/Min rohstoffe/Produkte/Volatilitaetsmonitor/vm 19 02pdf;jsessionid=E8FB53B1A11D8B10C5B13F79B6596F0F2_ cid292? blob=publicationFile\&v=2 Accessed 8 April 2019

Destatis.de 2017

Devlin W, Woods S, Coates, B (2011) Commodity price volatility. Paper published ahead of the G20 Finance Deputies meeting in Paris on 17-18 February for the Australian Government. https://treasury.gov. $\mathrm{au} / \mathrm{publication} /$ economic-roundup-issue-1-2011/economicroundup-issue-1-2011/commodity-price-volatility/ Accessed 2 March 2019

Djukanovic G (2016) Copper vs. aluminium — substitution slows but continues. Aluminium Insider, https://aluminiuminsider.com/ copper-vs-aluminium-substitution-slows-but-continues/, Accessed 2 March 2019

Drexhage JR, La Porta D, Hund KL, Mccormick MS, Ningthoujam J (2017) The growing role of minerals and metals for a low carbon future. World Bank Group, EGPS (Extractives Global Programmatic Support), Washington DC

EC (European Commission) (2017a) Critical Raw Materials, http://ec. europa.eu/growth/sectors/raw-materials/specific-interest/critical en Accessed 13 February 2019

EC (European Commission) (2017b) Communication from the Commission to the European Parliament, the Council, the European Economic and Social Committee and the Committee on the Regions on the 2017 list of Critical Raw Materials for the EU, 13.9.2017. https://ec.europa.eu/transparency/regdoc/rep/1/2017/ EN/COM-2017-490-F1-EN-MAIN-PART-1.PDF Accessed 13 February 2019

Elsner H (2012) Zur aktuellen Entwicklung bei Seltenen Erden für die Automatisierungstechnik. Quest-Trendmagazin. 23 July 2012. http://www.quest-trendmagazin.de/ressourcen/seltene-erden/ Interview-BGR.html Accessed 10 February 2019

Erdmann L, Graedel TE (2011) Criticality of non-fuel minerals: a review of major approaches and analyses. Environ Sci Technol 45(18): $7620-7630$

Erisman JW, Sutton MA, Galloway J, Klimont Z, Winiwarter W (2008) How a century of ammonia synthesis changed the world. Nat Geosci 1:636-639

Fay S (1982) Great silver bubble. Hodder \& Stoughton, London

Fesser G (2000) Die Kaiserzeit in Deutschland 1871-1918. Landeszentrale für politische Bildung Thüringen, Erfurt 2000, p 14. https://de.scribd.com/document/145731687/Gerd-FesserKaiserzeit Accessed 20 January 2019

Firebreak (2019) Product data sheet. https://wwwboraxcom/BoraxCorp/ media/Borax-Main/Resources/Data-Sheets/firebrake-zbpdf Accessed 28 February 2019

Foley NK, Jaskula BW, Kimball BE, Schulte RF (2017) Gallium. In: Schulz KJ, DeYoung JH, Seal II RR, Bradley DC (eds) Critical mineral resources of the United States- economic and environmental geology and prospects for future supply, USGS Professional Paper 1802-H: H1-H35

Frankel JA (2010) The natural resource curse: a survey. HKS faculty research working paper series, RWP10-005, John F. Kennedy School of Government, Harvard University

Gambogi J (2018) Rare earths. In: US geological survey mineral commodity summaries 2018:132-133

Global Industry Analysts Inc. (2010) Germanium-a global strategic business report. MCP 2637

Gocht WR, Zantop H, Eggert RG (1988) International mineral economics. Berlin, Heidelberg (Springer)

Green T (1999) The Millennium in Silver 1000-1999. Rosendale Press, London

Greenhill R, Miller R (1973) The Peruvian government and the nitrate trade, 1873-1879. J Lat Am Stud 5(1):107-131 http://www.jstor.org/ stable/156003 Accessed 16 February 2019

Hagelüken C (2005) Die Märkte der Katalysatorenmetalle Platin, Palladium und Rhodium. In: Hagelüken C, (ed) Autoabgaskatalysatoren-Grundlagen, Herstellung, Entwicklung, Recycling, Ökologie, Tübingen (Expert-Verlag)

Hagelüken C (2018) Catalyst recycling and supply-considerations for PGMs. Paper IFP School, Powertrain Engineering Programme, Paris 13.12.18 
Hagelüken C, Corti CW (2010) Recycling of gold from electronics: costeffective use through "Design for Recycling". Gold Bull 432:1-12

Hagelüken C, Meskers CEM (2010) Complex life cycles of Prcious and special metals. In: Graedel TE, van der Voet E (eds) Linkages of sustainability. Strüngmann forum reports. MIT Press, Cambridge MA, pp 163-197

Halme K, Piirainen KA, Vekinis G, Sievers EU, Viljamaa K (2012) Substitutionability of critical raw materials. Policy Department A: Economic and Scientific Policy, Directorate General for Internal Policies (eds), PE 492.448, Brussels https://www.researchgate.net/ publication/262198504 Substitutionability of Critical Raw Materials Accessed 15 January 2019

Haxel GB, Hedrick JB, Orris GJ (2002). Rare earth elements - critical resources for high technology. US Geol Survey Fact Sheet, 087-02

Hedrick JB (2010) Rare earths. In: US geological survey mineral commodity summaries 2010:128-129

Heeg T (2019) Mal was Neues, Frankfurter Allgemeine Zeitung $22.2 .2019, \mathrm{p} 24$

Herfindahl OC (1959) Copper costs and prices 1970-1957, Baltimore MD (Resources for the Future, Johns Hopkins Press)

Hertwich EG, Gibojn T, Bouman EA, Arvesen A, Suh S, Heath GA, Bergesen JD, Ramirez A, Vega M I, Shi L (2014) Integrated lifecycle Assessment of Electricity-Supply Scenarios confirms global environmental Benefit of low-carbon Technologies". In: Proceedings of the National Academy of Sciences of the USA, 2014. http://www.pnas.org/content/suppl/2014/10/02/1312753111. DCSupplemental Accessed 13 February 2019

Imran H, Durrani I, Kamran M, Abdolkader TM, Faryad M, Butt ZB (2018) High-performance bifacial perovskite/silicon doubletandem solar cell. IEEE J Photovoltaics 8(5):1222-1229

International Copper Study Group (ICSG) (2007 and 2018) The World Copper Factbook 2007/2018). https://de.scribd.com/document/ 7737663/2007-World-Copper-Fact-Book http://www.icsg.org/ index.php/press-releases/finish/170-publications-press-releases/ 2876-2018-10-08-icsg-factbook-2018 Accessed 25. January 2019

ITRI (2007) Tin use survey 2007, https://enwikipediaorg/wiki/File: TinConsChartjpg Accessed 2 February 2019

ITRI(2017) https://www.internationaltin.org/wp-content/uploads/2017/ 11/ITRI-2017-Tin-Use-Survey-Summary.pdf Accessed 2. February 2019

Jacks DS, O'Rourke KH, Williamson JG (2011) Commodity price volatility and world market integration since 1700. Rev Econ Stat 93(3): $800-813$

Jorge J (2019) International Lead and Zinc Study Group, Lisbon, personal communication 31.1.19

Jütte-Rauhut J (1989) Internationale Marktregulierungen als Risikofaktoren bei Projektfinanzierungen im Bergbau. Nomos, Baden-Baden

Kelley KD, Scott, CT, Polyak DE, Kimball BE (2017) Vanadium. In: Schulz KJ, DeYoung JH, Seal II RR, Bradley DC (eds) Critical mineral resources of the United States - economic and environmental geology and prospects for future supply, USGS Professional Paper 1802-U: U1-U36

Kelly TD, Matos GR, comps. (2017) Historical statistics for mineral and material commodities in the United States (2016 version): U.S. Geological Survey Data Series 140, https://minerals.usgs.gov/ minerals/pubs/historical-statistics/ Accessed 27 January 2019

Kesler SE (1994) Mineral resources, economics and the environment. Macmilllan, New York, p 224

Kestenbaum R (1991) The tin man - a chronicle of crisis. Surry/UK (Metal Bulletin Books, Worcester Park

Kilian 1 (2009) Not all oil price shocks are alike: disentangling demand and supply shocks in the crude oil market. Am Econ Rev 99(3): 1053-1069
Kingsnorth DJ (2013) Rare earths: an industry undergoing rejuvenation. Perth/ Australia (Curtin University, Industrial Minerals Company of Australia (IMCOA)), June 2013

Kingsnorth DJ (2015) The global green economy: opportunities \& threats for the rare earths industry, paper 5. In Proceedings of the Freiberg innovation symposium, Freiberg, 25-26 March 2015

Kingsnorth DJ (2018) Rare earth supply today: "lacking diversity for long term sustainability". Perth/ Australia (Curtin University, Industrial Minerals Company of Australia (IMCOA)), October 2018

Klochko K (2018) Antimony. In: US geological survey mineral commodity summaries 2018:22-23

Kohlscheen E, Avalos G, Schrimpf A (2017) When the walk is not random: commodity prices and exchange rates. Int J Cent Bank 13(2): $121-158$

Koren M, Tenreyro S (2007) Volatility and development. Q J Econ 122(1):243-287

Korinek, J. (2013) Mineral resource trade in Chile: contribution to development and policy implications, OECD Trade Policy Papers, No. 145, OECD Publishing, Paris. https://doi.org/10.1787/ 5k4bw6twpf24-en Accessed 30 May 2019

Kuck PH (1985) Vanadium in: US Bureau of mines mineral facts and problems. Bulletin 675:895-916

Lee J, Kitchaev DA, Kwon DH, Lee CW, Papp JK, Liu YS, Lun S, Clément RJ, Shi T, BD MC, Guo J, Balasubramanian M, Ceder G (2018, Nature) Reversible Mn2+/4+double redox in lithium-excess cathode materials. 556:185-190

Li J, Chen M, Cullen DA, Hwang S, Wang M, Li B, Liu K, Karakolos S, Lucero M, Zhang H, Lei C, Xu H, Sterbinsky GE, Feng Z, Su D, More KL, Wang G, Wang Z, Wu G (2018) Atomically dispersed manganese catalysts for oxygen reduction in proton-exchange membrane fuel cells. Nature Catalysis 1:935-945

Liebig J von (1840) Die organische Chemie in ihrer Anwendung auf Agricultur und Physiologie Braunschweig (Viewig)

Liedtke M, Elsner H (2009) Seltene Erden. Commodity top news Nr, 31st edn. Bundesanstalt für Geowissenschaften und Rohstoffe, Hannover

Liedtke M, Huy D. (2018) Rohstoffbewertung-gallium, DERARohstoffinformation 35, Berlin 2018

Loayza N, Raddatz C (2006), The structural determinants of external vulnerability, World Bank Policy Research Working Paper No. 4089

Lucas R (1988) On the mechanics of economic development. J Monet Econ XXII:3-42

Mallory IA (1990) Conduct unbecoming: the collapse of the international tin agreement. Am Univ Int Law Rev 5(3):835-892

Johnson Matthey 2018 PGM Market Report May 2018. http://www. platinum.matthey.com/documents/new-item/pgm\%20market $\%$ 20reports/pgm_market_report_may_2018pdf. Accessed 29 March 2019

McConnell D (1935) The Chilean nitrate industry. J Polit Econ 43:506529

McFadden E (1986) The collapse of tin: restructuring a failed commodity agreement. Am J Int Law 80(4):811-830. https://doi.org/10.2307/ 2202064

McKinsey \& Co (2019) Global energy insight 2019. https:/www. mckinsey.com/industries/oil-and-gas/our-insights/global-energyperspective-2019 Accessed 10 March 2019

Meadows DH, Meadows DL, Randers J, Behrens WW III (1972) The limits to growth, a report for the Club of Rome's Project on the predicament of mankind. Universe Books, New York

Melcher F, Buchholz P (2014) Germanium. In: Gunn G (ed) Critical metals handbook. Wiley, Chichester, UK, pp 177-203

Ministerio de Economía, Fomento y Turismo de Chile (2015) Insolvencia y quiebra en Chile, Principales estadísticas desde 1982 hasta la fecha, Santiago, Chile http://www.economia.gob.cl/wp-content/ uploads/2015/06/Insolvencia-y-Quiebra-en-Chile.pdf Accessed 1 April 2019 
Ministerio de Hacienda de Chile (1925) Antecedentes sobre la Industria Salitrera, Ministerio de Hacienda Sección Salitre, Santiago, Chile https://www.bcn.cl/obtienearchivo?id=documentos/10221.1/44070/ 1/120209.pdf\&origen=BDigital Accessed 1 April 2019

Morales JA, Sachs J (1987) La crisis económica en Bolivia, Documento de Trabajo, No. 08/87. In: Instituto de Investigaciones SocioEconómicas (IISEC). Universidad Católica Boliviana, La Paz

Murph D (2008) Worldwide LCD TV shipments surpass CRTs for first time ever, https://www.engadget.com/2008/02/19/worldwide-lcdtv-shipments-surpass-crts-for-first-time-ever/. Accessed 12 April 2019

Nassar NT, Graedel TE, Harper EM (2015) By-product metals are technologically essential but have problematic supply. Sci Adv 1(3): e1400180

Ober J (2007) Strontium. In: US geological survey mineral commodity summaries 2007, Reston VA:158-159

Olivares-Galvan J, Leon F, Georgilakis P, Escarela-Pérez R (2010) Selection of copper versus aluminum windings for distribution transformers. Electric Power Applications, IET 4:474-485. https:// doi.org/10.1049/iet-epa.2009.0297 https://www.researchgate.net/ publication/224152739_Selection_of_Copper_versus_Aluminum Windings_for_Distribution_Transformers Accessed 11 March 2019

Oxford Institute for Energy Studies (2018) Peak oil demand and long-run oil price. https://www.oxfordenergy.org/wpcms/wp-content/ uploads/2018/01/Peak-Oil-Demand-and-Long-Run-Oil-PricesInsight-25.pdf Accessed 11 March 2019

Packey DJ, Kingsnorth D (2016) The impact of unregulated ionic clay rare earth mining in China. Res Policy 48:112-116

Polyak DE (2018) Vanadium In: US geological survey mineral commodity summaries 2018, Reston VA 180-181

Popper K (1988) The open universe - an argument for indeterminism. Hutchinson, London

Raddatz C (2008) External shocks and macroeconomic volatility in Latin America. Unpublished manuscript

Radetzki M, Warell L (2017) A handbook of primary commodities in the global economy. Cambridge UK (Cambridge University Press)

Ramey G, Ramey VA (1995) Cross country evidence on the link between volatility and growth. Am Econ Rev 85(5):1138-1158

Renn O, Bradshaw AM, Dreyer M, von Gleich A, Gößling-Reisemann S, Großkurth P, Hussinger P, Lehnhoff S, Lermer E, Madlener R, aus dem Moore N, Scharte B, Thoma K, Weimer-Jehle W, Wellmer FW (2017) Risiko und Resilienz im Energiesystem. acatech-National Academy of Science and Engineering, German National Academy of Sciences Leopoldina. Union of the German Academies of Sciences and Humanities, Schriftenreihe Energiesyteme der Zukunft. Berlin, Munich. https://www.acatech.de/Publikation/dasenergiesystem-resilient-gestalten-szenarien-handlungsspielraeumezielkonflikte/ Accessed 23 February 2019

Robinius M, Linßen J, Grube T, Reuß M, Stenzel P, Syranidis K, Kuckertz P, Stolten D (2018) Comparative analysis of infrastructures: Hydrogen Fueling and Electric Charging of Vehicles. Publications of the Helmholtz-Research Center Jülich, Series Energy \& Environment 408

S\&P-Standard \& Poor's market intelligence (2019) Metals \& Mining Property Search.-commercial online-database. New York, January 2019

Sachs J (1987) The Bolivian hyperinflation and stabilization. Am Econ Rev 77(2):279-283 http://econ.sciences-po.fr/sites/default/files/file/ bolivia_sachs.pdf Accessed 20 February 2019

Schebek L, Becker BF (2014) Substitution von Rohstoffen Rahmenbedingungen und Umsetzung. In: Kausch P, Bertau M, Gutzmer, J, Matschullat J (eds) Strategische RohstoffeRisikovorsorge, Berlin, Heidelberg (Springer Spektrum):3-12

Schmidt M (2015) Rohstoffrisikobewertung-Platingruppenmetalle. DEAR Rohstoffinformationen, Berlin, p 26
Scholz RW, Wellmer FW (2013) Approaching a dynamic view on the availability of mineral resources: what we may learn from the case of phosphorus? Glob Environ Chang 23:11-27

Schüler-Zhou Y (2018) Chinas Rohstoffpolitik für seltene Erden. Commodity Top News 57, Bundesanstalt für Geowissenschaften und Rohstoffe, Hannover, Germany

Schulz JH, DeYoung Jr JH, Seal II RR, Bradley DC (2017) Critical mineral resources of the United States - economic and environmental geology and prospects for future supply. US Geological Survey Professional Paper 1802

Schumpeter J (1912) Theorie der wirtschaftlichen Entwicklung. Eine Untersuchung über Unternehmergewinn, Kapital, Kredit, Zins und den Konjunkturzyklus. Duncker \& Humblot, Berlin, p 157

Schwarz-Schampera U (2014a) Antimony. In: Gunn G (ed) Critical metals handbook. Wiley, Chichester UK, pp 70-98

Schwarz-Schampera U (2014b) Indium. In: Gunn G (ed) Critical metals handbook. Wiley, Chichester UK, pp 204-229

Shankleman J, Biesheuvel T, Ryan J, Merill D (2017) We're going to need More Lithium. Bloomberg Businessweek https://www. bloomberg.com/graphics/2017-lithium-battery-future/ Accessed 26 February 2019

Smil V (2001) Enriching the earth, Fritz Haber, Carl Bosch and the Transformation of World Food Production. MIT Press, Cambridge MA

Taleb N (2007) The black swan. The impact of the highly improbable. Allan Lane, London

Thomas CL (2018) Germanium. In: US geological survey mineral commodity summaries 2018:68-69

Thomas WI, Thomas DS (1928) The child in America: behavior problems and programs. Alfred A. Knopf, New York

Tilton JE (2003) On borrowed time: assessing the threat of mineral depletion. Resources for the Future, Washington DC, p 30

Tilton JE, Crowson PCF, DeYoung JH Jr, Eggert RG, Ericsson M, Guzmán JI, Humphreys D, Lagos G, Maxwell P, Radetzki M, Singer DA, Wellmer FW (2018) Public policy and future mineral supplies. Res Policy 57:55-60

Treleaven S (2019) Vanadium's day. CIM magazine 6.2.2019 https:// magazine.cim.org/en/operations/vanadiums-day-en/ Accessed 25 February 2019

UN Comtrade Database (2019) https://comtrade.un.org/. Accessed 27 June 2019

UKERC (United Kingdom Energy Research Centre) (2013) Materials availability. Comparison of material criticality studiesmethodologies and results (Working Paper III)

Urquart J (2018) Manganese makeover for lithium-ion batteries. Chemistry World https://www.chemistryworld.com/news/ manganese-makeover-for-lithium-ion-batteries/3008886.article Accessed 2 February 2019

US Department of Justice and Federal Trade Commission (2010) Horizontal Merger Guidelines https://www.ftc.gov/system/files/ documents/public_statements/804291/100819hmg.pdf Accessed 27 February 2019

USGS - U.S. Geological Survey (various years) Gallium Statistics and Information. - Minerals Information, Minerals Yearbook https:// minerals.usgs.gov/minerals/pubs/commodity/gallium/ Accessed 3 March 2019

USGS - U.S. Geological Survey Historical Statistics for Mineral and Material Commodities in the United States (2019), https://www. usgs.gov/centers/nmic/historical-statistics-mineral-and-materialcommodities-united-states. Accessed 27 May 2019

VCI 2016 (Verband der Chemischen Industrie) VCIStatement: on the proposal for a harmonised classification of titanium dioxide https:// www.vci.de/langfassungen/langfassungen-pdf/2016-07-04-vcistatement-titanium-dioxide.pdf Accessed 29 March 2019

Vidal O, Goffé B, Arndt N (2013) Metals for a low-carbon society. Nat Geosci 6:894-896 
Viebahn P, Soukup O, Samadi S, Teubler J, Wiesen K, Ritthoff M (2015) Assessing the need for critical minerals to shift the German energy system towards a high proportion of renewables. Renew Sust Energ Rev 49:655-671

Wagner M, Wellmer FWW (2009) A hierarchy of natural resources with respect to sustainable development - a basis for a natural resources efficiency indicator. In: Richards JP (ed) mining society and a sustainable world. Springer, Heidelberg, Dordrecht, pp 91-121

Wall F (2014) Rare earth elements. In: Gunn G (ed) Critical metals handbook. Wiley, Chichester UK, pp 312-339

Wellmer FW (2008) Reserves and resources of the geosphere, terms so often misunderstood. Is the life index of reserves of natural resources a guide to the future? Z. dt. Ges Geowiss, 159,4:575-590 https://doi. org/10.1127/1860-1804/2008/0159-0575

Wellmer FW (2012) Sustainable development and mineral resources. Géosciences 15:8-15

Wellmer FW, Dalheimer M (2012) The feedback control cycle as regulator of past and future mineral supply. Mineral Deposita 47(7):713729

Wellmer FW, Hagelüken C (2015) The feedback control cycle of mineral supply, increase of raw material efficiency, and sustainable development. Minerals 5:815-836

Wellmer FW, Schmidt H (1989) Versorgungslage bei Rohstoffen. Stahl und Eisen 109(2):55-60

Wellmer FW, Scholz RW (2017) Peak minerals: what we can learn from the history of mineral economics and the cases of gold and phosphorus. Miner Econ 30(2):73-93

Wellmer FW, Dalheimer M, Wagner M (2008) Economic evaluations in exploration. Springer, Berlin, Heidelberg

Wellmer FW, Buchholz P, Gutzmer J, Hagelüken C, Herzig P, Littke R, Thauer RK (2018) Raw materials for future energy supply. Springer, Berlin, Heidelberg
WI (Wuppertal Institut für Klima, Umwelt, Energie GmbH) (2014) KRESSE - Kritische mineralische Rohstoffe bei der Transformation des deutschen Energieversorgungssystems, final report for the German Federal Ministry for Economics and Energy Wuppertal, Germany: http://wupperinst.org/de/projekte/details/wi/ $\mathrm{p} / \mathrm{s} / \mathrm{pd} / 38 /$ Accessed 13 February 2019

Wisniak J, Garcés I (2001) The rise and fall of the Salitre (sodium nitrate) industry. Indian J Chem Technol 8:427-438 https://www. researchgate.net/publication/236233368_The_Rise_and_Fall_of the Salitre Sodium Nitrate Industry Accessed 6 April 2019

Witzig T (1981) Operation of the International Tin Agreement, Bureau of Mines Information Circular No. 8860, 1981. https://archive.org/ details/operationofinte00witz/page/n7 Accessed 17. February 2019

WMD (2018) Austrian Federal Ministry of Sustainability and Tourism (2018) World Mining Data 2018. https://wwwworld-miningdatainfo/wmd/downloads/PDF/WMD2018pdf Accessed 25 March 2019

World Bank (2015) A practical guide to increasing mining local procurement in West Africa (English). World Bank Group, Washington, DC http://documents.worldbank.org/curated/en/266701468119062079/ A-practical-guide-to-increasing-mining-local-procurement-in-WestAfrica. Accessed 13 April 2019

Zhao-Karger Z, Liu R, Dai W, Li Z, Diemant T, Vinayan BP, Minella B, Yu X, Manthiram A, Behm RJ, Fichter M (2018) Toward highly reversible magnesium-sulfur batteries with efficient practical practical MgB(hfip) 42 electrolyte. ACS Energy Lett 3(8):2005-2013

Publisher's note Springer Nature remains neutral with regard to jurisdictional claims in published maps and institutional affiliations. 